\title{
Aquatic Coleoptera of North Oman, with description of new species of Hydraenidae and Hydrophilidae
}

\author{
Ignacio RIBERA ${ }^{1)}$, Carles HERNANDO ${ }^{2)} \&$ Alexandra CIESLAK $^{1)}$ \\ 1) Institute of Evolutionary Biology (CSIC-Universitat Pompeu Fabra), Passeig Maritim de la Barceloneta 37, E-08003 Barcelona, Spain; \\ e-mails: Ignacio.Ribera@ibe.upf-csic.es, a.cieslak@gmx.net \\ 2) P.O. box 118, E-08911 Badalona, Catalonia, Spain; e-mail: leptotyphlus@gmail.com
}

\author{
Accepted: \\ $10^{\text {th }}$ June 2019 \\ Published online: \\ $24^{\text {th }}$ June 2019
}

\begin{abstract}
We report the aquatic Coleoptera (families Dryopidae, Dytiscidae, Georissidae, Gyrinidae, Heteroceridae, Hydraenidae, Hydrophilidae and Limnichidae) from North Oman, mostly based on the captures of fourteen localities sampled by the authors in 2010. Four species are described as new, all from the Al Hajar mountains, three in family Hydraenidae, Hydraena (Hydraena) naja sp. nov., Ochthebius (Ochthebius) alhajarensis sp. nov. (O. punctatus species group) and $O$. (O.) bernard sp. nov. (O. metallescens species group); and one in family Hydrophilidae, Agraphydrus elongatus sp. nov. Three of the recorded species are new to the Arabian Peninsula, Hydroglyphus farquharensis (Scott, 1912) (Dytiscidae), Hydraena (Hydraenopsis) quadricollis Wollaston, 1864 (Hydraenidae) and Enochrus (Lumetus) cf. quadrinotatus (Guillebeau, 1896) (Hydrophilidae). Ten species already known from the Arabian Peninsula are newly recorded from Oman: Cybister tripunctatus lateralis (Fabricius, 1798) (Dytiscidae), Hydraena (Hydraena) gattolliati Jäch \& Delgado, 2010, Ochthebius (Ochthebius) monseti Jäch \& Delgado 2010, Ochthebius (Ochthebius) wurayah Jäch \& Delgado, 2010 (all Hydraenidae), Georissus (Neogeorissus) chameleo Fikáček \& Trávníček, 2009 (Georissidae), Enochrus (Methydrus) cf. tetraspilus Régimbart, 1903, Laccobius (Hydroxenus) leucaspis Kiesenwetter, 1870, Paracymus relaxus Rey, 1884 (all Hydrophilidae), Dryops lutulentus (Erichson, 1947) (Dryopidae), and Augyles flavidus (Rossi, 1794) (Heteroceridae). A total of 73 species of aquatic Coleoptera are presently known from Oman, although this number is expected to increase substantially with further sampling. A checklist of the species of aquatic Coleoptera from the Arabian Peninsula is provided.
\end{abstract}

Key words. Coleoptera, Dryopidae, Dytiscidae, Georissidae, Gyrinidae, Heteroceridae, Hydraenidae, Hydrophilidae, Limnichidae, new species, new records, Oman

Zoobank: http://zoobank.org/urn:lsid:zoobank.org:pub:ABBA2B4F-8B60-41E2-B80B-45861F974B23

(C) 2019 The Authors. This work is licensed under the Creative Commons Attribution-NonCommercial-NoDerivs 3.0 Licence.

\section{Introduction}

The knowledge of the aquatic Coleoptera of the Arabian Peninsula has increased considerably in the last decade, largely through the effects of two collaborative projects: the publication of the five volumes of the Arthropod Fauna of the UAE, edited by Antonius van Harten, and the Italian and Czech explorations of the fauna of Socotra, which in many cases included also the study of other areas of the Arabian mainland (summarised in BEZDĚK \& HÁJEK 2017). Mostly as a result of these two initiatives 20 species of aquatic Coleoptera have been described from the
Arabian Peninsula since 2009, and many more have been newly recorded for the area. The large number of newly described species, especially in family Hydraenidae and in the southeast area of the Peninsula, could, however, be interpreted as a clear sign that the knowledge of the fauna is still very incomplete.

The first works dedicated to the aquatic Coleoptera of the Arabian Peninsula reported the results of the 1937-38 British Museum Expedition to South-West Arabia (HinTON 1948, Balfour-Browne 1951). BALFour-Browne (1951) is the single contribution with the largest number 
of new species described from the area, ten, in families Dytiscidae, Hydraenidae and Hydrophilidae. The series Fauna of Saudi Arabia published several papers between 1981 and 1997 (BRANCUCCI 1979, 1980, 1981, 1985; Rocchi 1984; Gentili 1989; Hebauer 1997), with occasional records from neighbouring countries. The fauna of Yemen and south Oman (the Dhofar region) was reviewed by HÁsEK \& REITER (2014), and that of the UAE by different authors (FIKÁČEK 2009; FIKÁČEK \& TRÁVNIČEK 2009; MASCAGNI 2009a,b,c; FIKÁČEK et al. 2010; JÄCH \& Delgado 2010, 2014; Hásek 2011; Hájek \& BrancucCi 2011). Thus, the only region of the Arabian Peninsula which so far has not been subject of a dedicated study is north Oman. To fill this gap we report the results of a trip to north Oman by the three authors in 2010, together with a summary of the fauna of the aquatic Coleoptera of the Arabian Peninsula. Among our captures there were four species new to science (three Hydraenidae and one Hydrophilidae), which we describe herein.

\section{Material and methods}

We sampled 14 localities in north Oman between 5-10 April 2010 (Table 1; Figs 1-13). In what follows we detail the species collected and the localities in which they were found, including in some cases additional material obtained from other sources. Exact label data are cited for the type material of the new species. A double slash (//) separates different lines and a comma (,) different labels. Additional remarks are found in square brackets.

We include as previously published records only the works which contain detailed original captures from Oman, not general catalogues or secondary references. The checklist of the species of the Arabian Peninsula (excluding Kuwait, the Sinai and Jordan) (Table 2) is mostly based on the current version of the Palaearctic catalogues, updated whenever appropriate.

Digital photographs of the habitus were taken with a Canon EOS 760D camera (Canon Inc., Tokyo, Japan) fitted

Table 1. Sampled localities in north Oman by the authors in 2010 (see Fig. 1 for their location, and Figs 2-13 for some photographs).

\begin{tabular}{|c|c|c|c|c|}
\hline Loc. no. & date & locality & coordinates & m a.s.l. \\
\hline 1 & 5.iv.2010 & Ad Dakhiliyah: Jebel Al-Akhdar, Rd J. Shams, ca. Ghul spring with pools & $\mathrm{N} 23^{\circ} 11^{\prime} 01.7^{\prime \prime} \mathrm{E} 57^{\circ} 08^{\prime} 30.4^{\prime \prime}$ & 908 \\
\hline 2 & 5.iv.2010 & Ad Dakhiliyah: Jebel Al-Akhdar, Bahla, wadi in city, residual pools & $\mathrm{N} 22^{\circ} 57^{\prime} 42.1^{\prime \prime} \mathrm{E} 57^{\circ} 17^{\prime} 47.5^{\prime \prime}$ & 559 \\
\hline 3 & 6.iv. 2010 & Ad Dakhiliyah: Jebel Al-Akhdar, rd. Tanuf-Hat, residual pools in wadi & $\mathrm{N} 23^{\circ} 05^{\prime} 36.2^{\prime \prime} \mathrm{E} 57^{\circ} 25^{\prime} 56.6^{\prime \prime}$ & 1307 \\
\hline 4 & 6.iv. 2010 & Al Batinah South: Jebel Al-Akhdar, source of wadi Bani Awf, on rock & $\mathrm{N} 23^{\circ} 10^{\prime} 36.2^{\prime \prime} \mathrm{E} 57^{\circ} 24^{\prime} 34.1^{\prime \prime}$ & 1300 \\
\hline 5 & 6.iv.2010 & Al Batinah South: Jebel Al-Akhdar, wadi Bani Awf, village below source & $\mathrm{N} 23^{\circ} 11^{\prime} 38.6^{\prime \prime} \mathrm{E} 57^{\circ} 23^{\prime} 41.7^{\prime \prime}$ & 917 \\
\hline 6 & 6.iv. 2010 & Al Batinah South: Jebel Al-Akhdar, wadi Bani Awf, residual pools & $\mathrm{N} 23^{\circ} 13^{\prime} 42.9^{\prime \prime} \mathrm{E} 57^{\circ} 25^{\prime} 25.8^{\prime \prime}$ & 660 \\
\hline 7 & 7.iv.2010 & Al Batinah South: Jebel Al-Akhdar, wadi Bani Awf, residual pools & $\mathrm{N} 23^{\circ} 17^{\prime} 23.8^{\prime \prime} \mathrm{E} 57^{\circ} 28^{\prime} 03.9^{\prime \prime}$ & 487 \\
\hline 8 & 7.iv.2010 & Ad Dhahirah: Murri env., wadi Bani Ghafir, stream with pools & $\mathrm{N} 23^{\circ} 29^{\prime} 46.2^{\prime \prime} \mathrm{E} 56^{\circ} 53^{\prime} 34.8^{\prime \prime}$ & 759 \\
\hline 9 & 8.iv.2010 & Ash Sharqiyah North: Said Bin Sahran env., wadi Indam, Rd. 33 residual pools & $\mathrm{N} 22^{\circ} 45^{\prime} 15.2^{\prime \prime} \mathrm{E} 58^{\circ} 00^{\prime} 56.9^{\prime \prime}$ & 463 \\
\hline 10 & 9.iv.2010 & Ash Sharqiyah North: Muqal, wadi Bani Khalid residual pools & $\mathrm{N} 22^{\circ} 36^{\prime} 16.9^{\prime \prime} \mathrm{E} 59^{\circ} 05^{\prime} 15.2^{\prime \prime}$ & 649 \\
\hline 11 & 9.iv.2010 & Ash Sharqiyah North: $15 \mathrm{~km} \mathrm{SW} \mathrm{Sur,} \mathrm{residual} \mathrm{pools} \mathrm{in} \mathrm{wadi} \mathrm{Rd.} 23$ & $\mathrm{~N} 22^{\circ} 27^{\prime} 51.9^{\prime \prime} \mathrm{E} 59^{\circ} 23^{\prime} 15.2^{\prime \prime}$ & 85 \\
\hline 12 & 9.iv.2010 & Ash Sharqiyah North: $1 \mathrm{~km} \mathrm{~W}$ Qalhat, residual pools in wadi & $\mathrm{N} 22^{\circ} 41^{\prime} 25.4^{\prime \prime} \mathrm{E} 59^{\circ} 22^{\prime} 03.0^{\prime \prime}$ & 88 \\
\hline 13 & 10.iv. 2010 & Muscat: Bamah, marsh next to motorway & $\mathrm{N} 23^{\circ} 12^{\prime} 34.4^{\prime \prime} \mathrm{E} 58^{\circ} 55^{\prime} 34.6^{\prime \prime}$ & 15 \\
\hline 14 & 10.iv. 2010 & Muscat: Al-Rija env., wadi Al-Mayb, residual pools & $\mathrm{N} 23^{\circ} 24^{\prime} 34.2^{\prime \prime} \mathrm{E} 58^{\circ} 31^{\prime} 26.8^{\prime \prime}$ & 139 \\
\hline
\end{tabular}

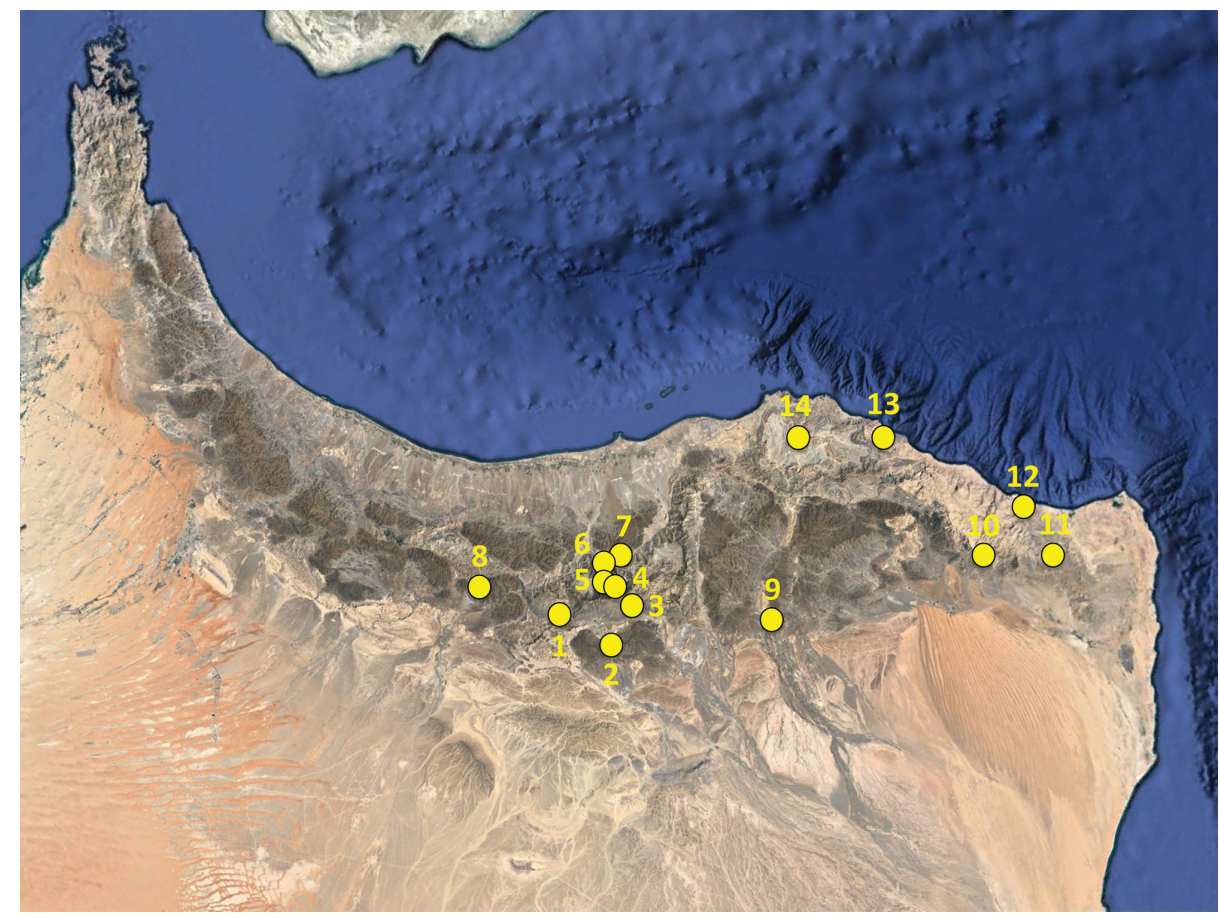

Fig. 1. Sampled localities (see Table 1 for details). 
to a Canon MP-E $65 \mathrm{~mm}$ macroscope. Image stacks were produced by hand, and combined using Zerene Stacker software (www.zerenesystems.com). We extracted the DNA of the specimens to be sequenced non destructively, with commercial kits (mostly DNeasy Tissue Kit, Qiagen, Hilden, Germany). We sequenced different combinations of mitochondrial and nuclear gene fragments depending on the taxonomic group (see PALlARÉs et al. 2017; VillastrIGO et al. 2018, 2019 for details on the primers used and reaction conditions). All genetic distances reported are uncorrected p-distances (i.e. the percentage of mismatches in the nucleotide sequence).

Unless otherwise stated, material is deposited in the CCHB and IBEB collections. Acronyms used in the text:

CCHB Carles Hernando collection, Badalona, Spain;

IBEB Institut de Biologia Evolutiva, Barcelona, Spain;

MNCN Museo Nacional de Ciencias Naturales, Madrid, Spain;

NHMW Naturhistorisches Museum Wien, Austria;

NMPC National Museum, Prague, Czech Republic;

SEMC Snow Entomological Collection, University of Kansas, USA;

ZSM Zoologische Staatssammlung, Munich, Germany.

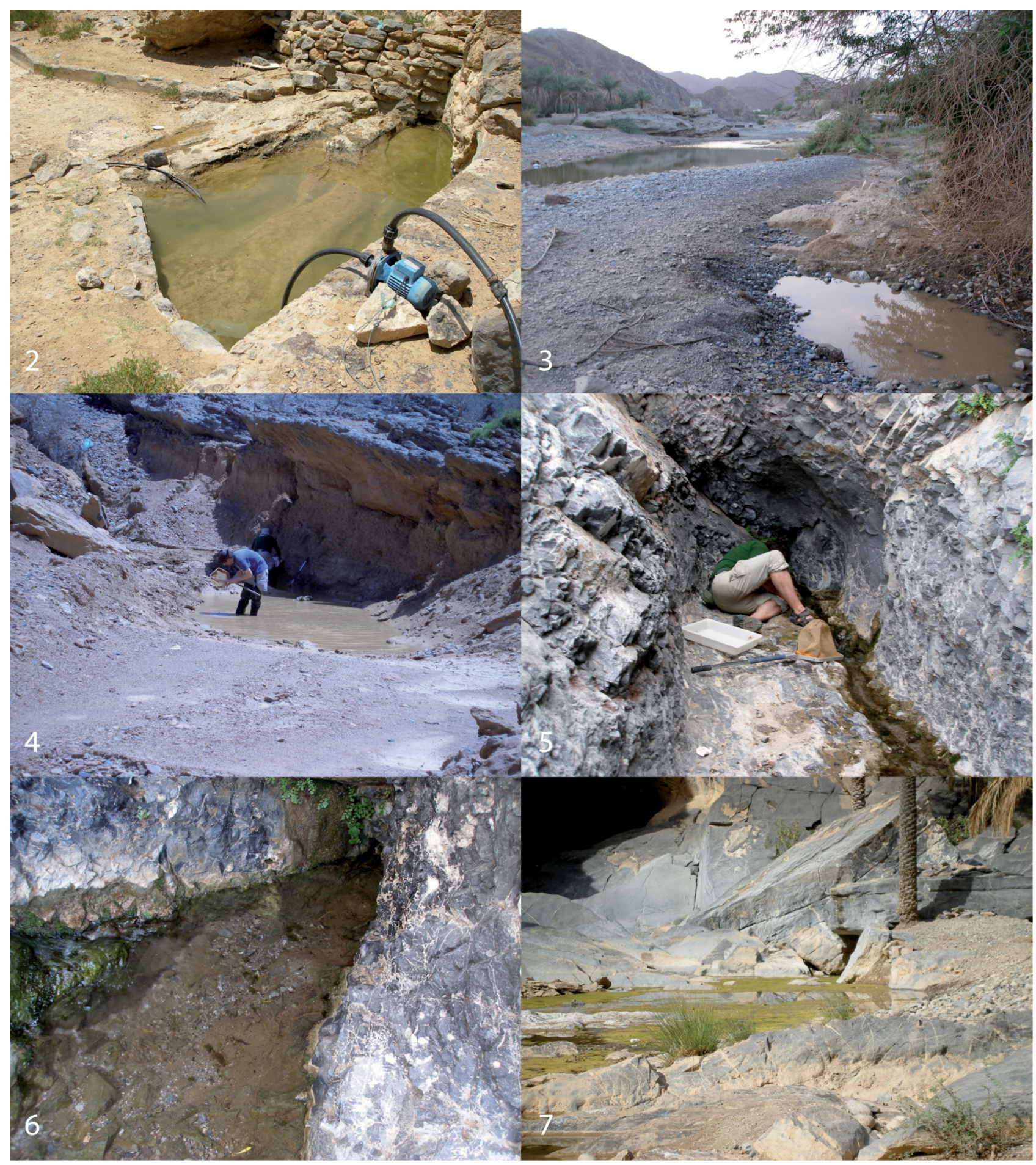

Figs 2-7. Some of the sampled localities in north Oman. 2 - Loc. No. 1: Ghul spring with pools; 3 - No. 2: residual pools in wadi in Bahla city; 4 - Loc. No. 3: residual pools in wadi; 5 - Loc. No. 4: source of wadi Bani Awf; 6 - Loc. No. 4: source of wadi Bani Awf; 7 - Loc. No. 5: wadi Bani Awf. See Table 1 for details on the localities, and Fig. 1 for their geographical location. 


\section{List of recorded species}

Adephaga

\section{Family Gyrinidae}

Dineutus (Cyclous) aereus (Klug, 1834)

Published records. Balfour-Browne (1951); Brancucci (1985); PederZANI (2003); HÁJEK \& ReITER (2014).

Material examined. Loc. 6: 1 spec.; Loc. 8: 4 spec.; Loc. 10: 4 spec.; Loc. 11: 4 spec. (plus 1 larva).
Dineutus (Cyclous) subspinosus (Klug, 1834)

Published records. Brancucci (1985); HÁJeK \& ReIter (2014). Material examined. Loc. 12: 8 spec.

\section{Family Dytiscidae \\ Copelatinae}

\section{Copelatus antoniorum Hájek \& Brancucci, 2011}

Published records. HÁJEK \& BRANCUCCI (2011).

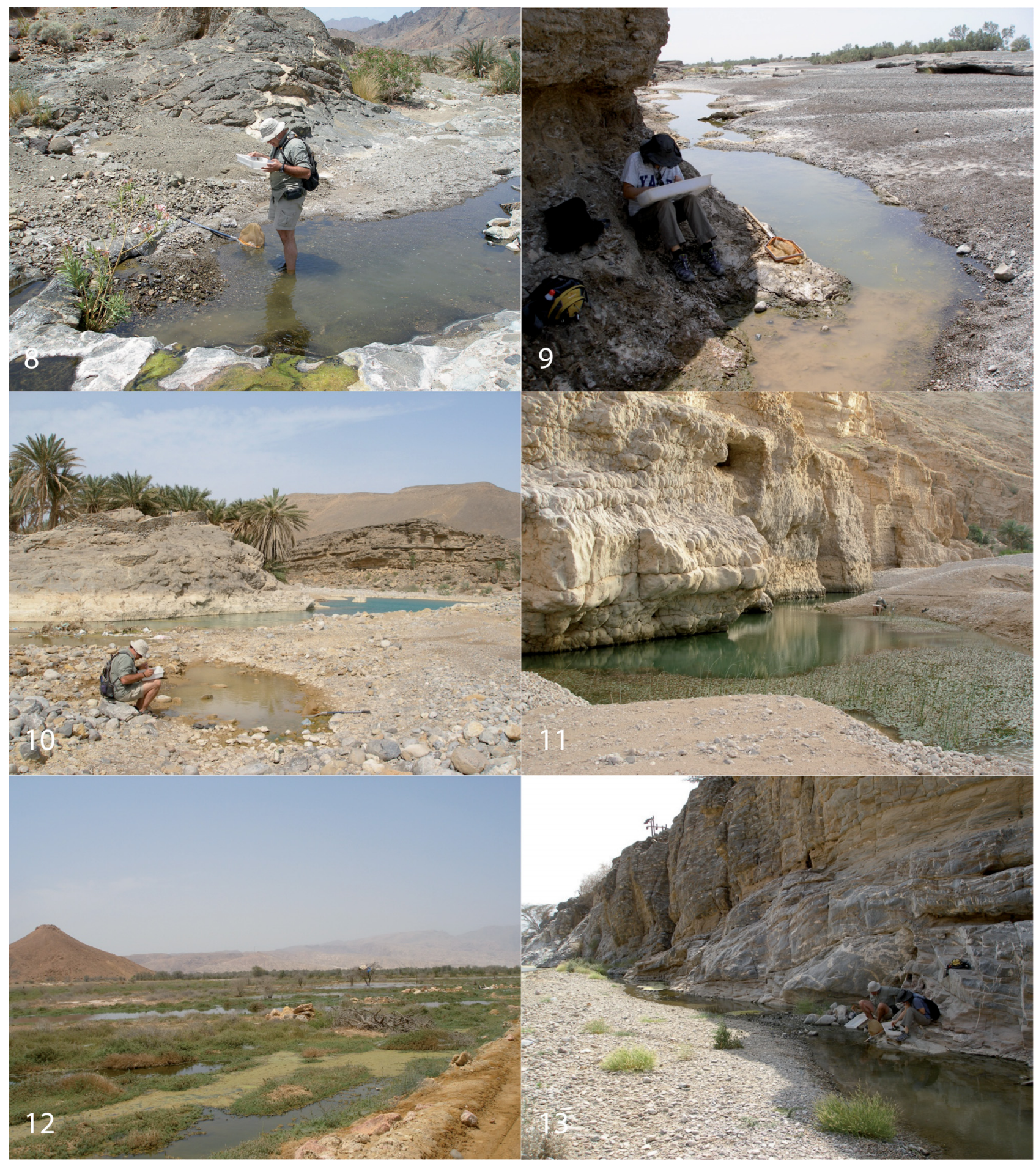

Figs 8-13. Some of the sampled localities in north Oman. 8 - Loc. No. 8: wadi Bani Ghafir; 9 - Loc. No. 9: residual pools in wadi Indam; 10 - Loc. No. 11: residual pools in wadi; 11 - Loc. No. 12: Qalhat, residual pools in wadi; 12 - Loc. No. 13: marsh next to Bamah; 13 - Loc. No. 14: residual pools in wadi Al-Mayb. See Table 1 for details on the localities, and Fig. 1 for their geographical location. 
Material examined. Loc. 6: $1 \bigcirc 1$ (designated as paratypes, deposited in the IBEB, ZSM) (HÁJeK \& Brancucci 2011).

Notes. We found the specimens in company of Copelatus gestroi (Sharp, 1882), in residual pools in the low reach of a wadi with some water running through filtration, a habitat very similar to those reported in the original description (HÁJEK \& BRANCUCCI 2011).

\section{Copelatus gestroi (Sharp, 1882)}

Published records. Shaverdo et al. (2008); Hájek \& Reiter (2014); WeWALKa \& Jäch (2017).

Material examined. Loc. 4: 2 spec.; Loc. 5: 2 q $;$ Loc. 6: 2 + ; Oman, Falah Cave, 2001, Sattmann leg.: 1 spec. (used for DNA extraction, voucher No. NHM-IR589, sequences published in Ribera et al. 2008).

\section{Cybistrinae}

\section{Cybister (Cybister) tripunctatus africanus Laporte, 1835}

Published records. Pederzani (2003); HÁJek \& Reiter (2014). Material examined. Oman, Wadi Jebel Abu Daud, 2316 $21^{\prime \prime} \mathrm{N}$ 58 47'26"E, 3.xi.2008 S. Carranza, E.N. Arnold \& S. Alrabei leg.: 1 ๆ.

\section{Cybister (Cybister) tripunctatus lateralis (Fabricius, 1798)}

Material examined. Oman, Al Hadd, $22^{\circ} 26^{\prime} 03^{\prime \prime} \mathrm{N} 59^{\circ} 38^{\prime} 49^{\prime \prime} \mathrm{E}$ 20.xi.2016, S. Carranza, M. Simó \& D. Fernández leg.: 1 đ.

Notes. New record for Oman. The last edition of the World catalogue of Dytiscidae (NILSSON \& HÁsEK 2018a) recognises three subspecies of $C$. tripunctatus in addition to the nominal form, two of them present in the Arabian Peninsula (C. $t$. africanus and C. t. lateralis). HÁJEK \& BRANCUCCI (2011) recorded the subspecies $C$. t. lateralis from the UAE based on specimens with a brown venter, in contrast to C. t. africanus, which has a black venter. However, GuIGNOT (1961) only recognised the nominal form, with brown venter and a wider posterior part of the elytra, and C. t. africanus, with a black venter and narrower elytra. We follow HÁJEK \& BRANCUCCI (2011) in considering this specimen, which has a brown venter, as C. t. lateralis, although the taxonomic status of the subspecies of $C$. tripunctatus may need to be revised.

\section{Cybister (Melanectes) vulneratus Klug, 1834}

Published records. Brancucci (1985); HÁJeK \& Reiter (2014). Material examined. Loc. 8: 1 O; Oman, Al Hadd, 22 $26^{\prime} 03^{\prime \prime} \mathrm{N}$ 59³8'49"E, 20.xi.2016, S. Carranza, M. Simó \& D. Fernández leg.: 1 . . Additional material: Oman, Dhofar region, Dhalkut, $16^{\circ} 44^{\prime} 54^{\prime \prime} \mathrm{N}$

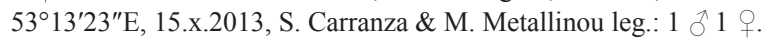

\section{Dytiscinae \\ Eretini}

\section{Eretes sticticus (Linnaeus, 1767)}

Published records. Brancucci (1980); Pederzani (2003); Hájek \& REITER (2014).

Material examined. Oman, Al Hadd, 22 $26^{\prime} 03^{\prime \prime} \mathrm{N} 59^{\circ} 38^{\prime} 49^{\prime \prime} \mathrm{E}$, 20.xi.2016, S. Carranza, M. Simó \& D. Fernández leg.: 2 † for DNA extraction, voucher No. IBE-AN688).

Notes. The identity of the species has been confirmed through the study of the COI gene (unpublished data).

\section{Hydaticini}

\section{Hydaticus (Prodaticus) histrio Clark, 1864}

Published records. BRANCUCCI (1985).

Material examined. Loc. 3: 1 (plus larvae); Loc. 6: 4 o 1 क; Loc.

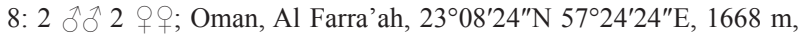
9.x.2005, S. Carranza, E.N. Arnold \& D. Donaire leg.: 1 q.

\section{Hydaticus (Prodaticus) pictus (Sharp, 1882)}

Published records. Balfour-Browne (1951); Brancucci (1985). Material examined. Loc. 6: $3 \hat{\delta} 29$; ; Loc. 7 (observed, no specimen collected); Oman, Fallah Cave, 21-27.i.2001, W. S. Giagang leg.: 2 spec. (one used for DNA extraction, voucher No. NHM-IR583, sequences published in RiBERA et al. 2008).

\section{Hydaticus (Prodaticus) servillianus Aubé, 1838}

Published records. HÁJEK \& REITER (2014).

Material examined. Loc. 13: 2 ㅇ․

\section{Hydroporinae \\ Bidessini}

\section{Glareadessus stocki Wewalka \& Biström, 1998}

Published records. Wewalka \& Biström (1998); Alarie \& WeWalka (2001) (description of the larvae).

Material examined. Loc. 2: $1 \mathrm{spec}$. (used for DNA extraction, voucher No. IBE-RA103); Loc. 5: 1 spec.; Loc. 6: 1 spec.; Loc. 8: 10 spec. (1 used for DNA extraction, voucher No. IBE-RA707); Loc. 12: 3 spec;

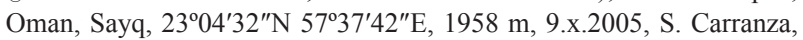
E.N. Arnold \& D. Donaire leg.: 1 spec.

Notes. The species was described from material collected with Bou-Rouch water pumps in the gravelly shore of wadis, "75-100 cm under the surface" (WEwALKA \& BisTRÖM 1998). Due to its uniformly pale colour, body shape and habitat it was considered to be a subterranean species, being even described as "stygobiont" despite the presence of well developed eyes and wings (AlARIE \& WEWALKA 2001). According to our observations the species inhabits the gravelly shores of wadis, mostly in residual pools, in which it could be found on the surface or just a few centimetres below the first layers of gravel. Likely due to the temporality of these habitats the species retains good flying abilities and well developed eyes, in contrast to other species with a similar appearance and habitat in the western Mediterranean, such as Graptodytes fractus (Sharp, 1882), or some populations of G. ignotus (Mulsant \& Rey, 1861).

\section{Hydroglyphus angularis (Klug, 1834)}

Published records. HÁJEK \& Reiter (2014).


voucher No. IBE-RA101).

\section{Hydroglyphus farquharensis (Scott, 1912)}

Material examined. Oman, Wadi Muqshin, $19^{\circ} 35^{\prime} 07^{\prime \prime} \mathrm{N} 54^{\circ} 53^{\prime} 03^{\prime \prime} \mathrm{E}$, 108 m, iv.2011, S. Carranza leg.: 6 spec. (1 q used for DNA extraction, voucher No. IBE-RA491).

Notes. New for the Arabian Peninsula. The species was described from the Seychelles, and has been recorded (under different synonyms) from Madagascar and southern and eastern Africa (BISTRÖM 1986). Externally the species 
is very similar to $H$. signatellus (Klug, 1834), although the male genitalia is very characteristic (BISTRÖM 1986). It is thus likely that some of the records of $H$. signatellus from the Arabian Peninsula may actually correspond to this species. The species was found in a saline source in the desert, close to the border with Saudi Arabia (S. Carranza, pers. comm. 2018).

\section{Hydroglyphus hormuzensis Hájek \& Brancucci, 2011}

\section{Published records. HÁJEK \& BRANCUCCI (2011).}

Material examined. Loc. 3: $1 \curvearrowright 1 \uparrow(1 \%$ designated as paratype, deposited in the IBEB, used for DNA extraction with voucher No. IBE-RA99); Loc. 8: 1 \%.

Notes. We found this species in a muddy residual pool with silt substratum, together with Ochthebius bernard sp. nov. and Hydraena naja sp. nov. (Fig. 4; see below) and in a stream (wadi) (localities numbers 4 and 8 respectively; Tables 1, 3 and Figs 5, 6, 8). As noted in the description (HÁJEK \& BRANCUCCI 2011), the male genitalia has two-segmented parameres, in contrast to the typical three-segmented parameres of the species of Hydroglyphus (BISTRÖM 1986). The inclusion of $H$. hormuzensis in the genus Hydroglyphus has to be revised, together with that of other species with two-segmented parameres (unpublished molecular results).

\section{Hydroglyphus signatellus (Klug, 1834)}

Published records. HÁJeK \& ReITer (2014).

Material examined. Loc. 2: 29 spec. (one used for DNA extraction, voucher No. IBE-RA102); Loc. 8: 1 †; Loc. 9: 6 spec.; Loc. 10: 2 spec.; Loc. 11: 19 spec.; Loc. 12: 11 spec.; Loc. 13: 9 spec.; Loc. 14: 6 spec.

\section{Hydroglyphus sinuspersicus Hájek \& Wewalka, 2009}

Published records. HÁJEK \& WEWALKa (2009).

Material examined. Loc. 1: 4 spec; Loc. 2: 6 spec.; Loc. 3: 80 spec. (1 used for DNA extraction, voucher No. IBE-RA100); Loc. 4: 2 spec.; Loc. 12: 1 .

Notes. The species was recently described with material from the UAE, north Oman (Al Houty [= Al Hoota] cave) and southwestern Iran, which had in part previously been misidentified as H. major (Sharp, 1882) (HÁJEK \& WEWALKA 2009). Hydroglyphus major seems to be confined to the Dhofar region, in south Oman (HÁJEK \& REITER 2014). The species is frequent in residual pools of wadis, sometimes in large numbers.

\section{Hydroporini}

\section{Nebrioporus mascatensis (Régimbart, 1897)}

Published records. Régimbart (1897); Brancucci (1985); HáJeK \& REITER (2014).

Material examined. Loc. 3: $1 \mathrm{spec}$. (very dark specimen); Loc. 4: $1 \mathrm{spec}$.; Loc. 5: 8 spec. (one used for DNA extraction, voucher No. IBE-RA107, sequences published in AbELLÁn et al. 2013, FERY \& RiBERA 2018); Loc. 6: 6 spec.; Loc. 7: 6 spec. (plus 1 larva); Loc. 8: 23 spec.

\section{Hyphydrini}

\section{Hyphydrus pictus Klug, 1834}

Published records. RÉGIMBART (1897) (as “Hyphydrus scriptus Klug”); Pederzani (2003); Hájek \& Reiter (2014).
Material examined. Loc. 1: 5 spec. (plus larvae) (one spec. used for DNA extraction, voucher No. IBE-RA555); Loc. 3: 3 spec.; Loc. 5: 1

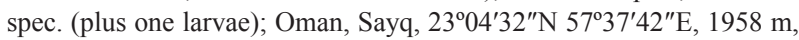
9.x.2005 S. Carranza, E.N. Arnold \& D. Donaire leg.: 1 spec. (used for DNA extraction, voucher No. IBE-RA549).

\section{Laccophilinae}

\section{Laccophilus maindroni maindroni Régimbart, 1897}

Published records. Régimbart (1897); BranCUCCI (1981, 1983, 1985); HÁJEK \& REITER (2014).

Material examined. Loc. 1: 3 spec.; Loc. 2: 1 spec.; Loc. 3: 1 spec.; Loc. 5: 1 spec. (plus larvae); Loc. 6: 17 spec.; Loc. 7: 7 spec.; Loc. 8: 10 spec.; Loc. 9: 3 spec. (plus larvae); Loc. 11: 7 spec.; Loc. 12: 7 spec.; Loc. 14: 9 spec.

$$
\begin{gathered}
\text { Polyphaga } \\
\text { Hydraenidae } \\
\text { Hydraeninae }
\end{gathered}
$$

\section{Hydraena (Hydraena) gattolliati Jäch \& Delgado, 2010}

Material examined. Loc. 4: $1 \hat{\delta}$.

Notes. New record for Oman. The species was described from the wadi Wurayah, in the northeastern UAE, which is also the type locality of Ochthebius wuraya Jäch \& Delgado, 2010. A third species of Hydraenidae was found in the same locality, Hydraena putearius Jäch \& Díaz, 2000 (J̈̈CH \& Delgado 2010). It is remarkable that the same three species were found in our locality 4 (Figs 5, 6), but with the addition of three new species, one Hydraena and two Ochthebius (see below).

\section{Hydraena (Hydraena) naja sp. nov. (Figs 14, 18)}

Type locality. Source of wadi Bani Awf in Jebel Al-Hajar, Oman (Loc. 4; Figs 1, 5, 6).

Type material. НоLотуре: $\widehat{\jmath}$ (NHMW), "4 Oman 6.4.2010 J. Al-Akhdar // source of wadi Bani Awf, on rock // N23 1036.2 E57 2434.1 1300m // Ribera, Cieslak \& Hernando leg.", aedeagus dissected and mounted in DMHF on a transparent card, with holotype label. PARATYPES ( $210 \mathrm{spec}$.) (CCHB, IBEB, MNCN, NHMW, NMPC): 15 of 13 우, same data as holotype, with paratype labels; 181 spec., "3 Oman 6.4.2010 J. Al-Akhdar // rd. Tanuf-Hat, residual pools in wadi // N23 05 36.2 E57 $2556.61307 \mathrm{~m}$ // Ribera, Cieslak \& Hernando leg." (1 spec. used for DNA extraction, voucher number IBE-RA97, sequences published in TRIzZINo et al. 2013 as "Hydraena sp. OMA"), with paratype labels; $1 \hat{\delta}$, "12 Oman 9.4.2010 $1 \mathrm{~km} \mathrm{~W}$ Qalhat // residual pools in wadi // N22 41 25.4 E59 $2203.088 \mathrm{~m}$ // Ribera, Cieslak \& Hernando leg.", with paratype labels.

Description. Habitus of male as in Fig. 14; body length: 2.30-2.75 mm, width: 0.90-1.10 mm.

Elytra, legs, palpi and antennae reddish brown; pronotum darker except for anterior margin, head almost black. Apex of maxillary palpi dark brown. Anterior margin of labrum deeply excised, with coarse punctures. Clypeus entirely densely punctate, matt. Central area of frons less densely punctate, with fine sparse pubescence between punctures; lateral parts of frons (ocular groove) deeply impressed, densely micropunctate.

Pronotum distinctly cordiform, anterior margin concave. Surface very densely punctate, interstices densely micropunctate. Median longitudinal impression and 
oblique posterior admedian grooves shallow. Sublateral groove deep.

Elytra elongate, subparallel-sided, with about 15 rows of punctures, with nine to ten rows between suture and shoulder; rows usually very regular, except for an admedian area in anterior third and apical area; punctures small, very densely arranged with small recumbent whitish setae; intervals narrow, very slightly convex, glabrous. Explanate margin of elytra well developed, not reaching elytral apex, weakly serrate; elytral apices more or less separately rounded.

Male meso- and metatibiae with apical expansions on ventral side, larger on metatibiae. Female with unmodified tibiae.

Ventral surface covered with a very dense short pubescence, forming a plastron except for the last abdominal ventrites and two longitudinal glabrous areas on metaventrite; abdominal ventrites with a dense fringe of setae on posterior margin.

Aedeagus as in Fig. 18.

Differential diagnosis. The species seems to be most closely related to $H$. verstraeteni Ferro, 1984 from south Iran (Hormozgan) (FERRo 1984, JÄCH 1992, SKalE \& JäCH 2011), based on the external morphology and the male genitalia. Based on the studied material both species cannot be separated on its external morphology, and only differ in the shape of the median lobe and associated appendages of the male genitalia (see fig. 41

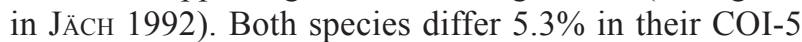
gene, based on a specimen of $H$. verstraeteni from south Iran (voucher IBE-AN461, prov. Khuzestan, Behbahan, Garmabeh river, 5.v.2011 E. Irani leg.). Phylogenetically both species are included in a clade with $H$. persica Janssens, 1981, H. dochula Jäch \& Skale, 2009 and related species, in turn related with the species of the $H$. grandis, H. rufipes and H. pulchella groups (TRIZZINO et al. 2013 and unpublished results).

Etymology. Named after the elapid snake genus Naja (cobras), in reference to the shape of the enlarged setae of the aedeagus (Fig. 18), resembling a cobra in its characteristic threatening position. Noun in singular nominative, standing in apposition.

Notes on the habitat. The species was most commonly found in two localities, residual pools in a wadi (locality No. 3) and the source of wadi Bani Awf (locality No. 4). The residual pool (Fig. 4) was the result of disruption by road works of a (by then) dry wadi, producing a pool with a diameter of ca. 3-4 m with muddy and sandy substratum and very turbid water. The species was here very abundant, together with Ochthebius bernard sp. nov. and Hydraena quadricollis Wollaston, 1864 (see below), plus other species in lower numbers. The source of wadi Bani Awf (Figs 5, 6) is a spring on a rocky surface, apparently at least partially artificially excavated to form a small tunnel through which the water is diverted to an artificial open channel that goes down the valley. When the locality was visited ( $6^{\text {th }}$ April) all the water was diverted through the channel, but occasionally the water should overflow it and run through a natural rocky bed, that at the time of our visit was completely dry. The distance between the spring and the channel was at most ca. $10 \mathrm{~m}$, with a rocky substratum with a thin layer of sand and gravel, with some green filamentous algae. Despite the reduced dimensions of the habitat the diversity was remarkably high, with six species of Hydraenidae, all of them endemic to Oman and the UAE and three of them newly described here (Hydraena naja sp. nov., H. gattolliati, H. putearius, Ochthebius bernard sp. nov., O. alhajarensis sp. nov., $O$. wurayah), in addition to Copelatus gestroi, Nebrioporus mascatensis and Hydroglyphus sinuspersicus.

Distribution. Found in the Al Hajar mountains, with an isolated specimen in a wadi in the coast of the Gulf of Oman (Fig. 1).

\section{Hydraena (Hydraenopsis) quadricollis Wollaston, 1864}

Material examined. Loc. 1: 6 spec.; Loc. 2: 3 spec.; Loc. 3: 65 spec. (1 $\delta$ used for DNA extraction, voucher No. IBE-RA98, sequences published in Trizzino et al. 2013); Loc. 6: 4 spec.; Loc. 7: 1 q.

Notes. New record for the Arabian Peninsula. The species was described from Tenerife (Wollaston 1864), and subsequently recorded from Cape Verde (Wollaston 1867), Algeria, Tunisia, Sudan, Ethiopia, Kenya (D'OrCHYMOnt 1940, BerthéLEmy et al. 1991) and Djibouti (JÄCH \& Delgado 2017). In Tenerife it was collected in several occasions on the same spot the same year, but not on subsequent years (Wollaston 1864). D'OrCHYMONT (1940) noted that the habitat in the type locality seemed to be unaltered but the species absent, concluding that it may have been an accidental temporary colonisation. D'ORCHYMONT (1940) established the synonymy of $H$. nilotica, described from the banks of the Nile in Egypt (lectotype and paralectotype designed in BERTHÉLEMY et al. 1991). In Trizzino et al. (2013) two specimens of $H$. quadricollis were included, one from Tunisia (voucher No. MNCN-AI1312, 24.x.2001, road between Ouessalatia and Kairouan, pond $5 \mathrm{~km}$ NW Rouissat, I. Ribera \& A. Cieslak leg.) and one of the specimens reported here from Oman (voucher number IBE-RA98, Loc. 3). Differences between the two specimens in the gene COI-3 were close to $5 \%$, which is well within the range of differences between well-established species of Hydraena (TrizzINO et al. 2013). The examination of these specimens, as well as further specimens from Egypt and Cape Verde, demonstrated some differences in the morphology of the aedeagus, but additional material from other areas should be examined to clarify the taxonomy of the complex.

\section{Hydraena (Phothydraena) putearius Jäch \& Díaz, 2000}

Published records. JäcH \& DíAZ (2000).

Material examined. Loc. 1: 13 spec. (1 o used for DNA extraction, voucher No. IBE-RA95, sequences published in ABELLAN \& RIBERA 2011; Abellán et al. 2013; TrizZINo et al. 2013; Villastrigo et al. 2019); Loc. 2: 5 spec.; Loc. 3: 55 spec.; Loc. 4: 5 spec.; Loc. 5: 14 spec.; Loc. 6: 6 spec.; Loc. 7: 9 spec.; Loc. 8: 60 spec.; Loc. 9: 2 spec.; Loc. 10: 4 spec.; Loc. 12: 69 spec. ( 1 used for DNA extraction, voucher No. IBE-RA706). 


\section{Limnebius (Bilimneus) wewalkai Jäch \& Delgado 2010}

Published records. Jäch \& Delgado (2010).

Material examined. Loc. 2: 4 spec.; Loc. 5: 2 spec.; Loc. 6: 62 spec. (2 of used for DNA extraction, voucher Nos IBE-AR32 and IBE-RA108, sequences published in Rudoy et al. 2016, Villastrigo et al. 2019); Loc. 7: 4 spec.; Loc. 8: 14 spec.; Loc. 9: 1523 spec.; Loc. 11: 11 spec.; Loc. 12: 5 spec.

\section{Ochthebiinae}

\section{Ochthebius (Ochthebius) alhajarensis sp. nov.} (Figs 15, 19)

Type locality. Source of wadi Bani Awf in Jebel Al-Hajar, Oman (Loc. 4; Figs 1, 5, 6).

Type material. Holotyp: $\precsim$ (NHMW), “4 Oman 6.4.2010 J. Al-Akhdar // source of wadi Bani Awf, on rock // N23 10 36.2 E57 24 34.1 1300m // Ribera, Cieslak \& Hernando leg.", used for DNA extraction, voucher number IBE-RA104 (sequences published in VILLASTRIGo et al. 2019), aedeagus dissected and mounted in DMHF on a transparent card, with holotype label. PARATYPES ( 4 spec.): (CCHB, IBEB): 390 , same data as holotype, with paratype labels; 1 o, "6 Oman 6.4.2010 J. Al-Akhdar // wadi Bani Awf residual pools // N23 13 42.9 E57 25 25.8 660m // Ribera, Cieslak \& Hernando leg.".

Description. Habitus as in Fig. 15. Body length: 2.15-2.25 mm; width: 0.90-0.95 mm. Dorsal surface black (dark brown in immature specimens); palpi, antennae and legs brown.

Upper surface of head with very long, adpressed fine whitish setae. Labrum only slightly incised, surface between punctures smooth. Frontoclypeal suture distinct, strongly arched. Surface of head largely smooth, with microreticulated areas around eyes and on neck area. With two large foveae on vertex; ocelli not visible.

Pronotum trapezoidal, almost as wide as long; surface covered with same type of setae as on head but more sparse; anterior margin straight in middle; anterior angles roughly arcuated; lateral margin irregularly defined. Hyaline membrane narrow at anterior and posterior margins, very wide at posterior corners. Surface of disk smooth, with sparse punctures and some microreticulation on margins; with shallow longitudinal and lateral furrows; sides of pronotum strongly microreticulated, with granulose appearance.

Elytra oval; with very irregular rows of shallow punctures, with long and thin whitish seta on anterior part of each puncture. Lateral rim smooth, not explanate. Membranous wings well developed.

Legs relatively long, with rows of strong setae, without natatorial setae.

Ventral surface black, surface shagreened, covered with long, thin, whitish pubescence. Margins of metaventrite and abdominal ventrites with shorter, more dense setae.

Aedeagus (Fig. 19) with main piece strongly bend in almost straight angle; medial part narrow, apex dilated and sinuated. Distal lobe regularly expanded, with lower part hyaline. Parameres inserted near base of main piece, not reaching its apex.

Differential diagnosis. Ochthebius alhajarensis sp. nov. belongs to the $O$. punctatus group. Among the species for which we have molecular data, it is most closely related to O. klapperichi Jäch, 1989 from central Asia (studied specimen voucher No. MNCN-AI1269; VILLASTRIGO et al. 2019) at a genetic distance of 7\% in the COI-3 gene, and both to another unnamed species from Tajikistan (unpublished data). They are in turn related to O. quadrifoveolatus Wollaston, 1854 and $O$. ragusae Kuwert, 1877, both widely distributed in the Mediterranean region (JÄCH \& SKALE 2015). From its known closest relative, O. klapperichi, and from O.quadrifoveolatus the new species differs clearly in the shape of the pronotum, with a much narrower base and stronger fossae. The external morphology is most similar to $O$. ragusae, from which based on the available material apparently only differs in the stronger punctuation of the elytra. The shape of the aedeagus is, however, clearly different to that of all these species (see JäcH 1989).

Etymology. Named after the mountain range of Al Hajar, in north Oman, were the new species was found; adjective. Notes on the habitat. The species was found in two localities, the source of the wadi Bani Awf (Figs 5, 6; see habitat notes for Hydraena naja sp. nov.) and residual pools downstream of the same wadi.

Distribution. Only known from two localities in the same stream in the Al-Hajar mountains (Fig. 1).

\section{Ochthebius (Ochthebius) bernard sp. nov. (Figs 16, 20)}

Type locality. Source of wadi Bani Awf in Jebel Al-Hajar, Oman (Loc. 4; Figs 1, 5, 6).

Type material. HоLотуре: $\curvearrowright$ (NHMW), “4 Oman 6.4.2010 J. Al-Akhdar // source of wadi Bani Awf, on rock // N23 10 36.2 E57 2434.1 1300m // Ribera, Cieslak \& Hernando leg.", aedeagus dissected and mounted in DMHF on a transparent card, with holotype label. PARATYPES (138 spec.) (CCHB, IBEB, MNCN, NHMW, NMPC): $2 \circ \circ$, same data as holotype, with paratype labels; 3 \ 3 q $\circ$, “1 Oman 5.4.2010 J. Al-Akhdar// Rd J. Shams, ca. Ghul spring with pools // N23 1101.7 E57 0830.4 908m // Ribera, Cieslak \& Hernando leg.", with paratype labels (1 1 used for DNA extraction, voucher number IBE-RA96); $130 \mathrm{spec}$."3 Oman 6.4.2010 J. Al-Akhdar// rd. Tanuf-Hat, residual pools in wadi // N23 0536.2 E57 25 $56.61307 \mathrm{~m} / /$ Ribera, Cieslak \& Hernando leg.", with paratype labels (1 $\checkmark$ used for DNA extraction, voucher number IBE-AN1102).

Additional material studied. 1 \%, "8 Oman 7.4.2010 Murri env. // wadi Bani Ghafir, stream with pools // N23 29 46.2 E56 53 34.8 759m // Ribera, Cieslak \& Hernando leg."

Description. Habitus as in Fig. 16. Body length: 1.95-2.20 mm; width: 0.90-0.95 mm. With a blackish metallic hue, immature specimens paler (dark brown); palpi dark brown, antennae yellowish except for the brown club, legs dark brown.

Upper surface of head with irregular, adpressed fine whitish setae. Labrum deeply incised, anteriorly upturned (more in males). Frontoclypeal suture distinct, strongly arched. Surface of head with a shagreened, almost rugose appearance, especially around two depressed fovea on vertex. Eyes large, with small, recumbent setae among ocelli. With two large ocelli behind fovea.

Pronotum trapezoidal, almost as wide as long; surface covered with same type of setae as on head; anterior margin straight in middle; anterior angles straight; lateral margin irregularly defined. Hyaline membrane narrow at anterior and posterior margins, very wide at posterior corners. Surface very densely punctate-granulated, with a rugose but shiny appearance; disc with a shallow 

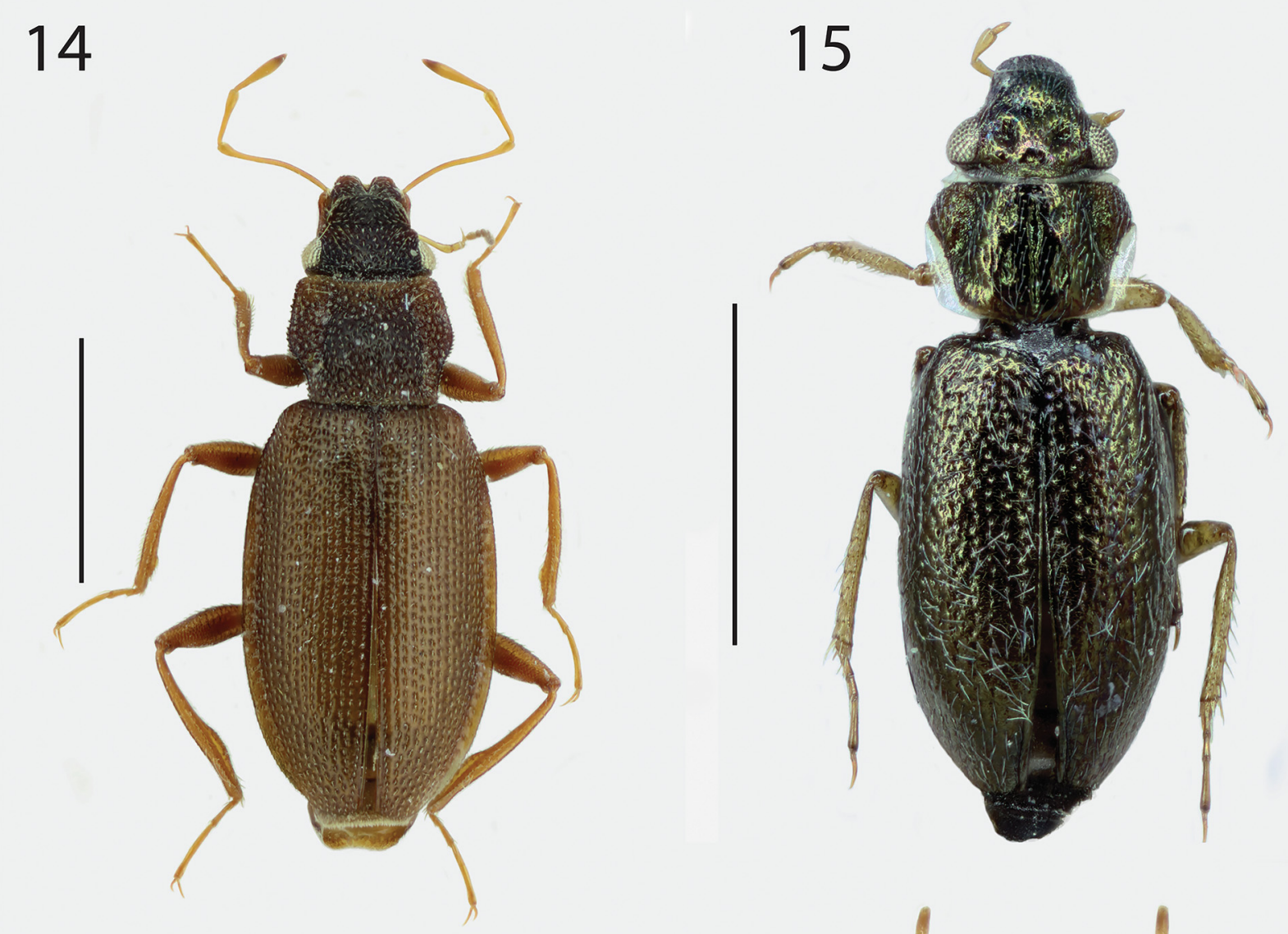

16
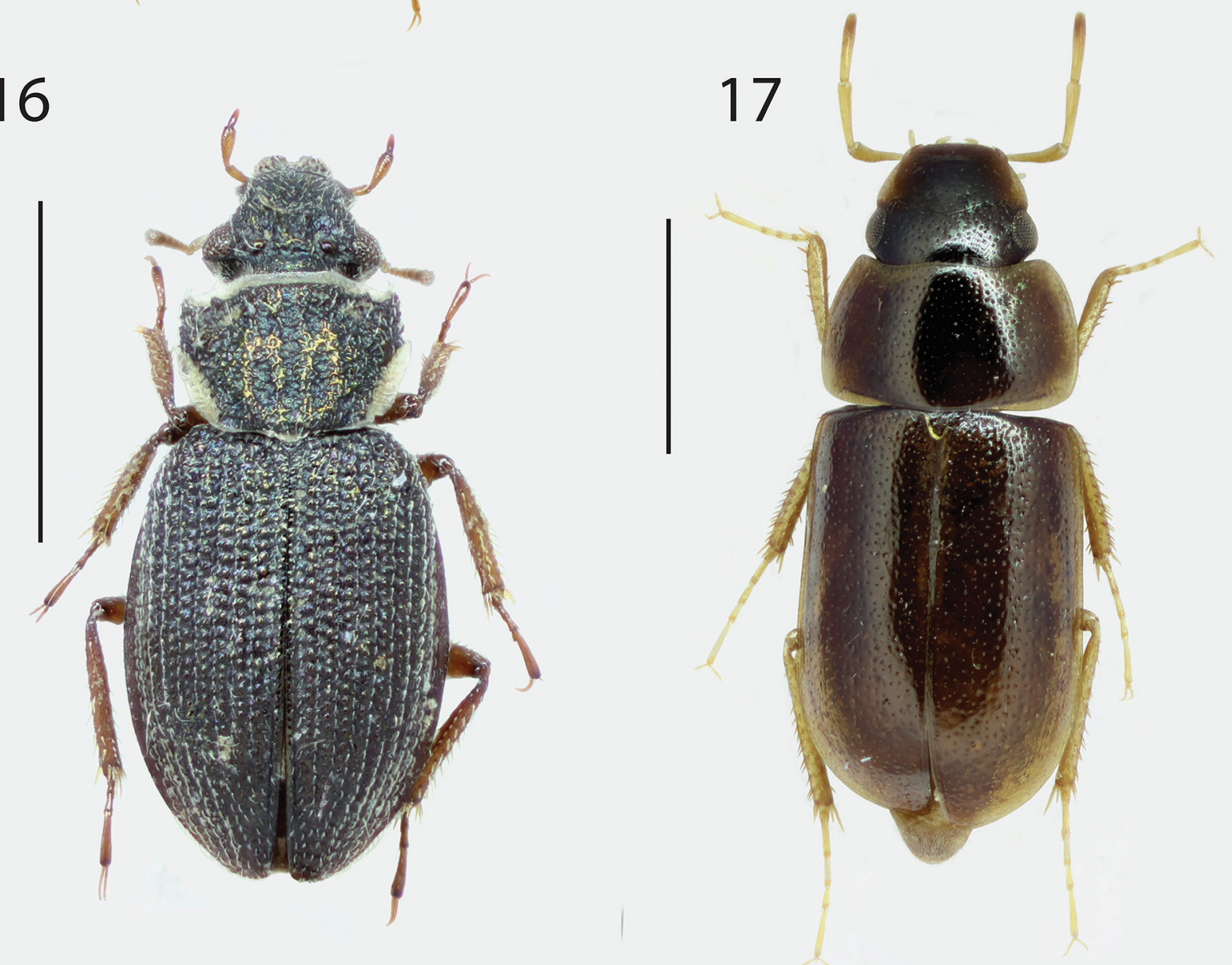

Figs 14-17. Habitus of new species: 14 - Hydraena naja sp. nov.; 15 - Ochthebius alhajarensis sp. nov.; 16 - Ochthebius bernard sp. nov.; 17 - Agraphydrus elongatus sp. nov. Scale bars: $1 \mathrm{~mm}$. 


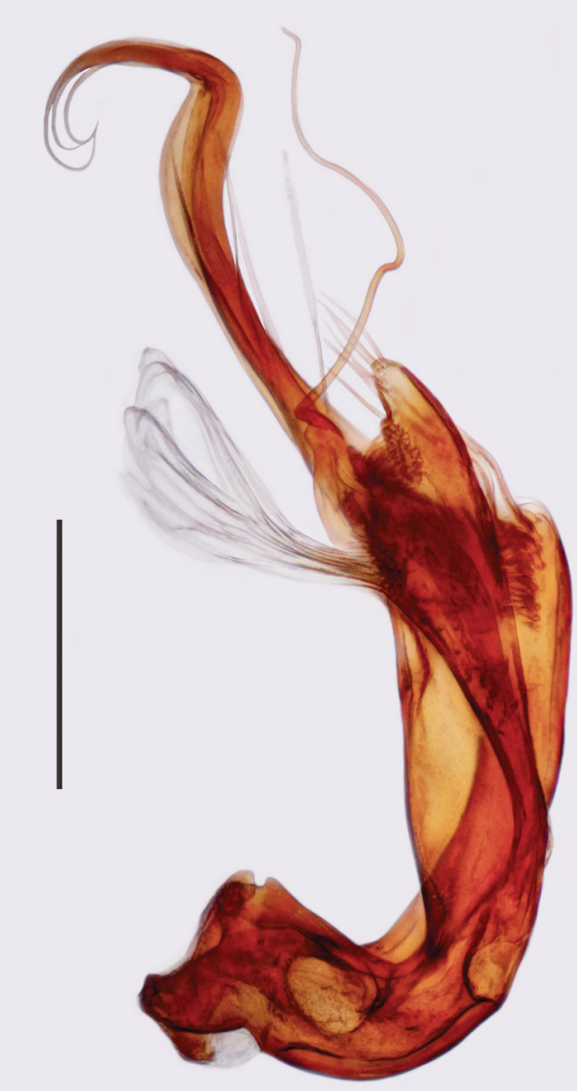

18

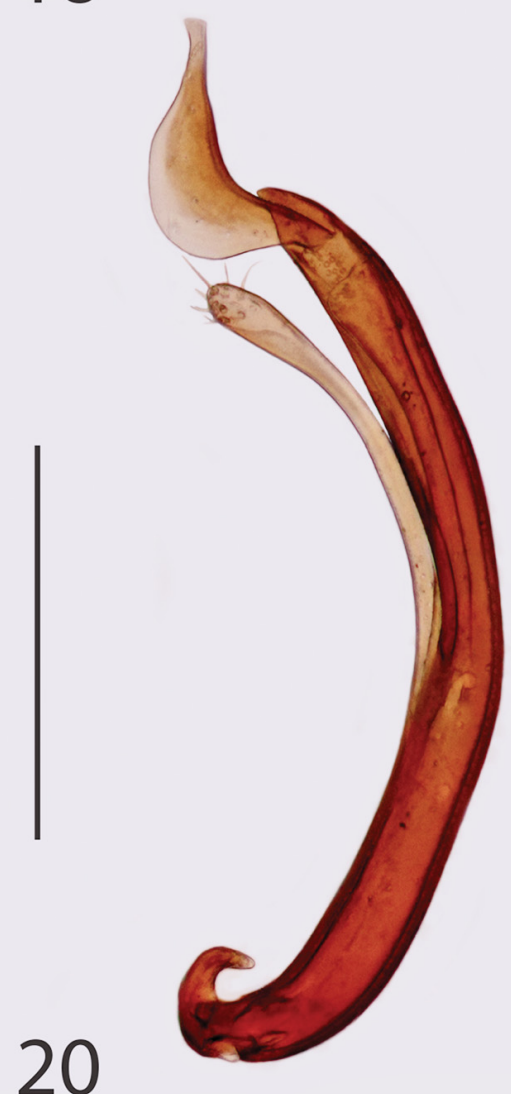

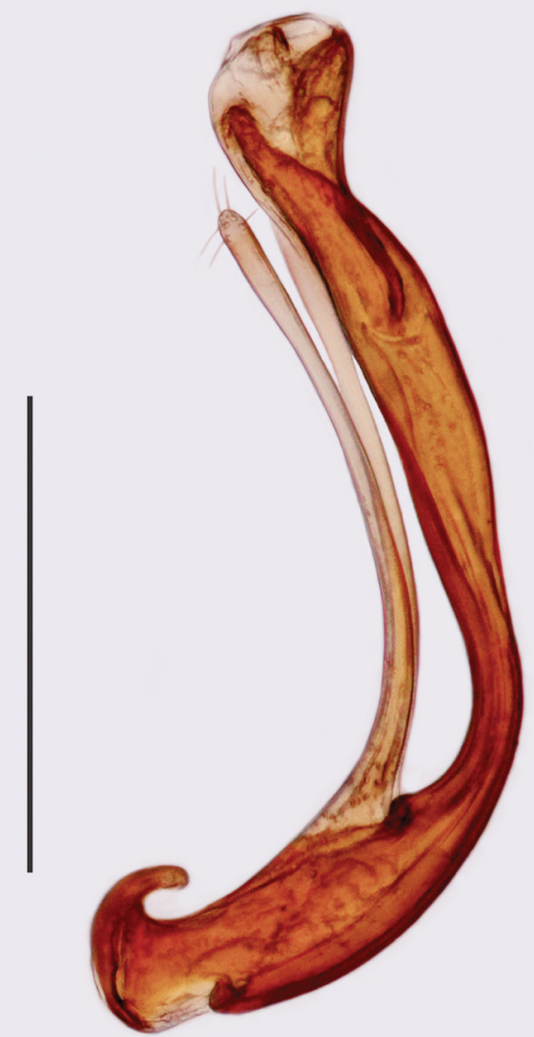

19

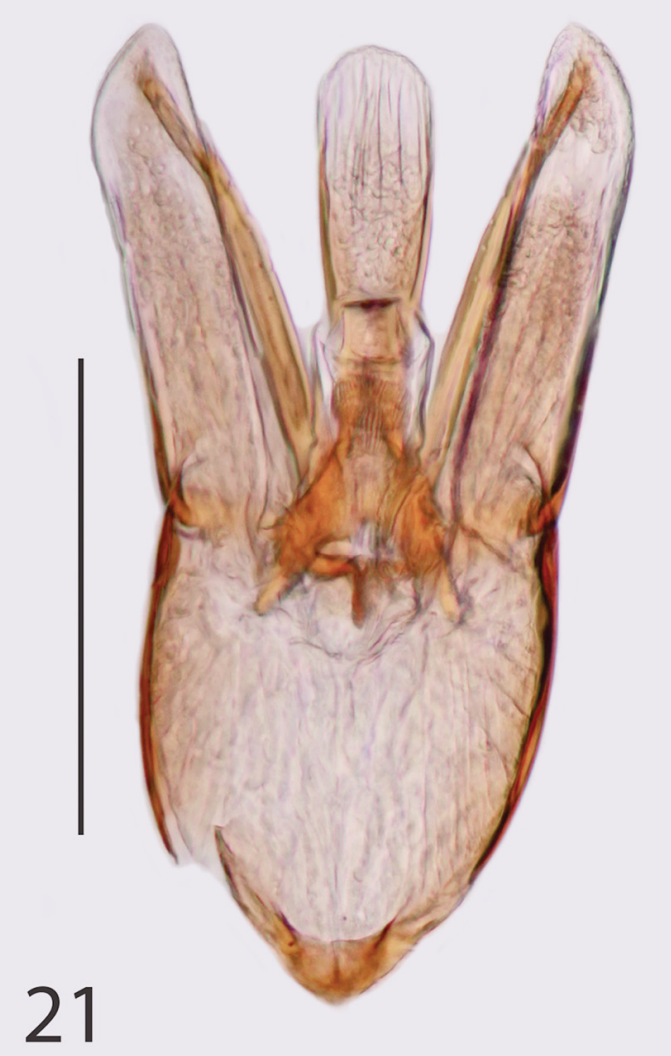

Figs 18-21. Aedeagus of new species: 18 - Hydraena naja sp. nov.; 19 - Ochthebius alhajarensis sp. nov.; 20 - Ochthebius bernard sp. nov.; 21 - Agraphydrus elongatus sp. nov. Scale bars: $0.2 \mathrm{~mm}$. 
irregular median groove and poorly defined, irregular lateral furrows.

Elytra oval; with regular rows of punctures and small tubercles, giving a rugose appearance; with a strong, adpressed seta on anterior part of each puncture. Lateral rim smooth, wider on females. Membranous wings well developed.

Legs short and robust, with rows of strong spine-like setae, without natatorial setae.

Ventral surface black, elytral epipleura and hypomera dark brown; covered with fine, dense uniform pubescence. Margins of metaventrite and abdominal ventrites with longer setae, more orderly disposed.

Aedeagus (Fig. 20) with main piece evenly curved, with uniform width. Distal lobe regularly expanded, with a tubuliform apex. Parameres inserted near median part of main piece, not reaching its apex.

Differential diagnosis. The new species belongs to the Ochthebius metallescens group, being most closely related to $O$. hivae Jäch et al., 2013 from western Iran. It differs from this species in the body colouration (brownish in $O$. hivae, black with metallic reflections in O. bernard sp. nov.), the less strongly granulated elytra, pronotum and head of $O$. hivae, the more acuminate elytra in $O$. hivae, and the shape of the aedeagus (see JÄCH et al. 2013). As noted in J $\mathrm{ÄCH}$ et al. (2013), the shape of the distal lobe of the aedeagus of $O$. hivae is unusually variable, but none of the different models figured matches the shape of the distal lobe of $O$. bernard sp. nov., specially those of the type locality (see Figs 2 and 3 in JäCH et al. 2013). The two species differ by ca. $10 \%$ in their COI-3 gene, as measured with one specimen of $O$. hivae from the type locality (specimen voucher IBE-RA744, Iran: prov. Khuzestan, Behbahan, Morvarid spring, 4.ix.2010, leg. E. Irani; ViLLASTRIGO et al. 2019). Despite the strong resemblance of the external morphology (see also J̈̈CH et al. 2013), $O$. bernard sp. nov. does not seem to be closely related to the only other species of the $O$. metallescens group from the Arabian Peninsula, O. wurayah Jäch \& Delgado, 2010 (unpublished results), with which it was found to coexist in our locality No. 4 (Table 3; Figs 5, 6).

Etymology. We name this species after the first and last authors' son, Bernard. Noun in nominative, standing in apposition.

Notes on the habitat. The species was most common in localities Nos 3 and 4 (Figs 1, 4-6; see description under Hydraena naja sp. nov. above).

Distribution. So far only known from the central Al-Hajar mountains (Fig. 1).

\section{Ochthebius (Ochthebius) harteni Jäch \& Delgado 2010}

Published records. Jäch \& Delgado (2010).

Material examined. Loc. 2: 3 spec. (1 spec. used for DNA extraction, voucher No. IBE-RA705, sequences published in Villastrigo et al. 2019); Loc. 3: 1 क; Loc. 11: 13 spec. (1 $\delta$ used for DNA extraction, voucher No. IBE-RA125, sequences published in ABELLÁn et al. 2013); Loc. 12: 11 spec.

\section{Ochthebius (Ochthebius) mahmoodi Jäch \& Delgado 2014}

Published records. JäCH \& DELGADO (2014).

Material examined. Loc. 8: 2 \% ; Loc. 12: 19 spec. (1 1 used for DNA extraction, voucher No. IBE-RA126, sequences published in ABELLÁN et al. 2013 as Ochthebius nr. difficilis; VILLASTRIGO et al. 2019).

Notes. Ochthebius mahmoodi was described based on specimens from the UAE and Oman, which in part had been misidentified as $O$. monseti Jäch \& Delgado, 2010, as both species were said to be indistinguishable based on external morphology (JäCH \& Delgado 2014). However, based on molecular data of specimens of both species from Oman they are not even sisters, being $O$. monset $i$ sister to the Iberian O. montesi Ferro, 1984, and O. mahmoodi sister to O. micans Balfour-Browne, 1951 (specimen from Djibouti), all at considerable genetic distance (VILLASTRIGO et al. 2019).

\section{Ochthebius (Ochthebius) monseti Jäch \& Delgado 2010}

Material examined. Loc. 10: 1 † ; Loc. 11: 26 spec. (1 $\precsim$ used for DNA extraction, voucher No. IBE-RA124, sequences published in ABELLÁN et al. 2013; Villastrigo et al. 2019).

Notes. New record for Oman. The species was described with material from UAE and southwestern Iran (JÄCH \& Delgado 2010), although the distribution of the species is somewhat uncertain, as part of the type material was subsequently recognised to be a different species, O. mahmoodi (see above). In addition to the specimen from Oman (voucher IBE-RA124) we have sequenced a specimen from Iran (voucher IBE-RA740, prov. Khuzestan, Behbahan, Garmabeh river, 5.v.2011, E. Irani leg.) and found them to be sisters, although at a considerable genetic distance (ca. 5\% in the gen COI-5', unpublished data).

\section{Ochthebius (Ochthebius) wurayah Jäch \& Delgado, 2010}

Material examined. Loc. 4: $3 \hat{\delta} 4+q(1 \precsim$ used for DNA extraction, voucher number IBE-AN1103).

Notes. New record for Oman. The species was so far only known from two localities in the UAE (JÄCH \& DELGADO 2010).

\section{Georissidae}

Georissus (Neogeorissus) chameleo Fikáček \& Trávníček, 2009

Material examined. Loc. 11: 3 spec.; Loc. 12: 1 .

Notes. New record for Oman. This is the only species of Georissidae known from the Arabian Peninsula, previously only recorded from the UAE (FIKÁČEK \& TRÁVNí̌EK 2009). All specimens from the UAE were collected at light or Malaise traps, with no data on their habitat. In Oman specimens were found on gravelly and sandy margins of wadis (Figs 10-11). 


\section{Hydrophilidae \\ Acidocerinae}

\section{Agraphydrus elongatus sp. nov.}

(Figs 17, 21)

Type locality. Wadi Bani Ghafir, Murri, Oman (Loc. 8; Figs 1, 8). Type material. Hоцотуре: (NHMW), "8 Oman 7.4.2010 Murri env. // wadi Bani Ghafir, stream with pools // N23 2946.2 E56 5334.8759 m // Ribera, Cieslak \& Hernando leg.", aedeagus dissected and mounted in DMHF on a transparent card, with holotype label. PARAtypes (88 spec.) (CCHB, IBEB, MNCN, NHMW, NMPC): 15 spec., same data as holotype, with paratype labels; 8 spec. "2 Oman 5.4.2010 J. Al-Akhdar // Bahla, wadi in city residual pools // N22 5742.1 E57 1747.5 559m // Ribera, Cieslak \& Hernando leg.", with paratype labels (1 $\delta$ used for DNA extraction, voucher number IBE-RA105); 6 spec. "6 Oman 6.4.2010 J. Al-Akhdar // wadi Bani Awf residual pools // N23 13 42.9 E57 2525.8 660m // Ribera, Cieslak \& Hernando leg.", with paratype labels; 1 spec. "7 Oman 7.4.2010 J. Al-Akhdar // wadi Bani Awf residual pools // N23 1723.8 E57 2803.9 487m // Ribera, Cieslak \& Hernando leg.”, with paratype label; 18 spec., "9 Oman 8.4.2010 Said Bin Sahran env. // wadi Indam, Rd. 33 residual pools // N22 4515.2 E58 0056.9 463m// Ribera, Cieslak \& Hernando leg.", with paratype labels; 1 “ “12 Oman 9.4.2010 $1 \mathrm{~km}$ W Qalhat // residual pools in wadi // N22 4125.4 E59 2203.0 88m // Ribera, Cieslak \& Hernando leg.", with paratype labels; 3 spec. "UAE: Ras al-Khaimah // (south), Wadi Shawkah // Hajar Mountains (UAE 3) // ca. 80 km ESE Dubai // 23.I.2010, leg. M.A. Jäch", "upper course //


"UAE: Ras al-Khaimah // (south) (UAE 10) // Hajar Mountains // ca. 80 km SE Dubai // 26.I.2010, leg. M.A. Jäch", "small stream // ca. 385 m a.s.1. // $25^{\circ} 03^{\prime} 25^{\prime \prime} \mathrm{N} / / 56^{\circ} 03^{\prime} 40.7^{\prime \prime} \mathrm{E}^{\prime}$; 19 spec. "UAE: Fujairah (UAE 12) // Wadi Maidaq // Hajar Mountains // 26.I.2010, leg. M.A. Jäch”, “ca. 8 km NW Masafi // ca. 75 km E Dubai // springfed streamlet in // canyon", "residual pools // ca. $386 \mathrm{~m}$ a.s.1. // 2520'48.7"N // 56 $05^{\circ} 28^{\circ} \mathrm{E}^{\circ}$; 16 spec. same label data, but "leg. K. Mahmoud".

Description. Habitus as in Fig. 17; total length: 2.00-3.10 mm, elytral width: $0.95-1.30 \mathrm{~mm}$. Habitus slender, elytra very weakly widening posterior to midlength, almost parallel-shaped, weakly convex. Labrum, clypeus and frons black, clypeus with narrow, undefined, yellow lateral margins; maxillary palpi yellow, palpomere 4 infuscated in apical third, pronotum dark brown with narrow yellowish margins, elytra dark brown in anterior two thirds, indistinctly brighter brown in posterior third, with very narrow, undefined, yellow lateral margins, ventrites dark brown, legs slightly lighter brown.

Clypeus with weakly concave anterior margin, microsculpture absent, punctures fine, interspaces about 2-3 $\times$ as wide as punctures. Eyes large, slightly protruding, oval-shaped. Maxillary palpi very slender, palpomere 4 asymmetrical. Mentum with few scattered fine punctures in lateral thirds, microsculpture absent.

Pronotal punctation as on head. Elytral punctation as on head and pronotum, four rows of punctures moderately distinct, mesal rows 1-3 strongly reduced in number of punctures, not reaching anterior margin.

Mesoventrite with a distinct mesal bulge. Abdominal ventrite 5 with uneven, roughly shaped apical margin, excision absent, or excision present, less than $8 \mu$ deep.

Pubescence present on less than proximal half of proand mesofemur, on proximal third of metafemur.

Aedeagus as in Fig. 21. Phallobase slightly shorter than parameres, evenly converging to weakly defined manubrium. Lateral margins of parameres not constricted subapically, weakly pointed, apex weakly sclerotized.
Median lobe slightly shorter than parameres, apex rounded. Differential diagnosis. Agraphydrus elongatus sp. nov. can be easily separated from A. minutissimus (Kuwert, 1890), the only other species of Agraphydrus known from the Arabian Peninsula (Table 2; both species coexisted in locality No. 8, Fig. 8; see Table 3 ), by the general colouration (pale brown in A. minutissimus, uniformly dark in A. elongatus sp. nov.) and the body shape (almost cylindrical, parallel-sided in A. elongatus, not widened posteriorly). The maxillary palpi are also longer than in A. minutissimus, and the species can also be recognised by the male genitalia. The two species belong to a species group including other small and slender species, although none with a similar body shape as $A$. elongatus sp. nov. (A. Komarek, pers. comm. 2018).

Etymology. Named in reference to the elongated body shape. The specific name is an adjective in nominative singular.

Notes on the habitat. The species was commonly found in wadis, both in residual pools with gravelly or sandy margins and in the areas with water flow, among stones and gravel (Figs 3, 7-9, 11).

Distribution. Oman and UAE (Fig. 1).

\section{Agraphydrus (Agraphydrus) minutissimus (Kuwert, 1890)}

Published records. Hebauer (1997).

Material examined. Loc. 8: 22 spec.

\section{Helochares (Hydrobaticus) crenatuloides d'Orchymont, 1943}

Published records. Hebauer (1997).

Material examined. Loc. 1: 11 spec.; Loc. 2: 1 1 1 .

\section{Chaetharthriinae}

\section{Thysanarthria wadicola Fikáček \& Liu, 2019}

Published records. HeBauer (1997, 2001, as T. sulcata (Chiesa, 1967)); FIKÁČEK \& LiU (2019).

Material examined. Loc. 8: 3 우 (paratypes, CCHB, IBEB), 1 spec. (paratype, SEMC, corresponding to voucher SLE0127 in SHORT \& FIKÁČEK 2013); Loc. 9: 1 (paratype, IBEB).

Notes. The species was recorded from Oman by HeBAuER $(1997,2001)$ as $T$. sulcata, and from the UAE and Iran by FIKÁČEK et al. (2010) with some doubts on its identity. A recent revision of the genus has shown that $T$. sulcata is a synonym of $T$. championi (Knisch, 1924), widespread in central and south Asia (FIKÁČEK \& LIU 2019). The Arabian material corresponds to a species newly described by FIKÁČEK \& LiU (2019), T. wadicola. Specimens were found in the gravelly shores of wadis, in a microhabitat similar to that of some species of the related genus Chaetharthria.

\section{Enochrinae}

\section{Enochrus (Lumetus) ater (Kuwert, 1888)}

Published records. Hebauer (1997).

Material examined. Loc. 13: 25 spec. (one used for DNA extraction, voucher No. IBE-AB267, sequences published in ArRIBAs et al. 2014, PALlarÉs et al. 2017). 


\section{Enochrus (Lumetus) politus (Küster, 1849)}

Published records. Hebauer (1997).

Material examined. Loc. 11: 4 spec. (plus 1 larva?); Loc. 13: $47 \mathrm{spec}$. (plus larvae?); Loc. 14: 1 spec.

\section{Enochrus (Lumetus) cf. quadrinotatus (Guillebeau, 1896)}

Material examined. Oman, Wadi Muqshin, $19^{\circ} 35^{\prime} 07^{\prime \prime} \mathrm{N} 54^{\circ} 53^{\prime} 03^{\prime \prime} \mathrm{E}$, 108 m, iv.2011, S. Carranza leg.: $1 \lesssim 1 \%$ ( used for DNA extraction, voucher No. IBE-RA490/IBE-RA553, sequences published in ARRIBAS et al. 2014; PALlarÉs et al. 2017)

Notes. Species new for the Arabian Peninsula. The studied specimens were tentatively identified as E. quadrinotatus in ArRiBas et al. (2014) and PALlARÉs et al. (2017), described from Syria, although it would be necessary to study the type material of this species to confirm the identification. According to the molecular data the species belongs to the E. bicolor complex, being sister to a clade including E. falcarius Hebauer, 1991, E. segmentinotatus (Kuwert, 1888), E. risii Arribas \& Millán, 2013 and E. cf. turanicus Schödl, 1998 (PALlarés et al. 2017). The male genitalia and external morphology are clearly different from E. sinuatus d'Orchymont, 1937 (see ScHöDL 1998) which was recorded from the UAE by FIKÁČEK et al. (2010).

\section{Enochrus (Methydrus) cf. tetraspilus Régimbart, 1903}

Material examined. Loc. 13:2 $ᄋ$ ㅇ.

Notes. New record for Oman. The species was recorded, with some doubts on its identity, from the UAE by FIKÁČEK et al. (2010). Our specimens $(2+9)$ agree well with the description provided by these authors.

\section{Hydrophilinae}

\section{Arabhydrus gallagheri Hebauer, 1997}

Published records. Hebauer (1997).

Material examined. Loc. 7: 2 spec.; Loc. 9: 1 9; Loc. 11: 2 spec.; Loc. 12: 1 ; Loc. 14: 51 spec. (one used for DNA extraction, voucher No. IBE-RA106, sequences published in Arribas et al. 2014; PALlarÉs et al. 2017) (2 spec. in SEMC); Oman, Wadi Mayh, $23^{\circ} 30^{\prime} 42^{\prime \prime} \mathrm{N} 58^{\circ} 38^{\prime} 40^{\prime \prime} \mathrm{E}$, 23.x.2008, S. Carranza, E. N. Arnold \& S. Alrabei: 1 spec.

\section{Berosus (Berosus) fuscostriatus Fairmaire, 1892}

Published records. Hebauer (1997).

Material examined. Oman, Al Hadd, $22^{\circ} 26^{\prime} 03^{\prime \prime} \mathrm{N} 59^{\circ} 38^{\prime} 49^{\prime \prime} \mathrm{E}$, 20.xi.2016, S. Carranza, M. Simó \& D. Fernández leg.: 11 spec.

\section{Berosus (Berosus) nigriceps (Fabricius, 1801)}

Published records. Hebauer (1997).

Material examined. Loc. 13: 33 spec.

\section{Berosus (Berosus) rubiginosus Kuwert, 1890}

Published records. Hebauer (1997).

Material examined. Loc. 1: 2 spec; Loc. 3: 4 spec.: Loc. 5: 1 ; Loc. 11: 1 ; Loc. 12: 20 spec.
Laccobius (Hydroxenus) leucaspis Kiesenwetter, 1870

Material examined. Loc. 8: $2 \hat{\jmath}$.

Notes. New record for Oman. The species had been previously recorded from Saudi Arabia (Hejaz mountains) by D’OrChyMONT (1936) (Table 2).

\section{Laccobius (Microlaccobius) orsenigoi Gentili, 1980}

Published records. FIKÁČEK et al. (2010).

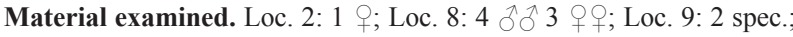
Loc. 10: 12 spec.; Loc. 11: 7 spec.; Loc. 12: 9 spec.

\section{Laccobius (Microlaccobius) praecipuus Kuwert, 1890}

Published records. Hebauer (1997).

Material examined. Loc. 1: 55 spec.; Loc. 2: 7 spec.; Loc. 3: $56 \lesssim ð 2$ १९; Loc. 5: 2 spec.; Loc. 6: 16 spec.; Loc. 8: 35 spec.; Loc. 9: 7 spec.; Loc. 10: 9 spec.; Loc. 11: 17 spec.; Loc. 12: 27 spec.; Loc. 14: 50 spec.

\section{Paracymus relaxus Rey, 1884}

Material examined. Loc. 13: 14 spec.

Notes. New record for Oman. The species had been previously recorded from Saudi Arabia, UAE and Yemen by BALFour-Browne (1951), HebAuer (1997) and FikÁČEK et al. (2010) (Table 2).

\section{Sternolophus decens Zaitzev, 1909}

Published records. Balfour-Browne (1951); Hebauer (1997); NASSERZADEH \& KoMAREK (2017).

Material examined. Loc. 6: 10 spec. (plus larvae, 2 spec. SEMC); Loc. 8: 6 spec. (plus larvae); Loc. 9: 2 spec.; Loc. 11: 2 spec.; Loc. 12: 1 .

Sphaeridiinae

Coelostoma (Holocoelostoma) stultum (Walker, 1858)

Published records. HEBAUER (1997).

Material examined. Loc. 13: 1 q.

\section{Coelostoma (Lachnocoelostoma) transcaspicum Reitter, 1906}

Published records. Hebauer (1997).

Material examined. Loc. 8: 5 spec.; Loc. 12: 1 spec.; Loc. 13: 3 spec.; Loc. 14: 4 spec.

\section{Dryopidae}

Dryops lutulentus (Erichson, 1947)

Material examined. Loc. 1: 1 ; Loc. 3: 1 q; Loc. 11: 1 đ.

Notes. New record for Oman. Dryops lutulentus has been recorded from the province of Hormozgan in Iran (DELÈVE 1970; Mascagni et al. 2016), Yemen, Saudi Arabia and UAE (Mascagni 2009a) (Table 2).

\section{Heteroceridae}

Augyles flavidus (Rossi, 1794)

Material examined. Loc. 9: 1 \%

Notes. New record for Oman. The species is widely distributed in the western Palaeartic and Ethiopian Regions, and was recorded from the UAE by MASCAGNI (2009c). 
Table 2. Checklist of the aquatic Coleoptera of the Arabian Peninsula. In bold, species newly recorded for Oman, including the new species described here. Yemen refers to continental part only (i.e. without Socotra). $\bullet \bullet$ indicates species reported in this work.

\begin{tabular}{|c|c|c|c|c|c|c|c|}
\hline No & species & Oman & UAE & S Arabia & Yemen & Bahrain & Qatar \\
\hline \multicolumn{8}{|c|}{ Dryopidae } \\
\hline 1 & Ahaggaria acutangula Bollow, 1938 & & & $\bullet$ & $\bullet$ & & \\
\hline 2 & Dryops cassius Hinton, 1848 & & & $\bullet$ & $\bullet$ & & \\
\hline 3 & Dryops gracilis (Karsch, 1881) & & & & $\bullet$ & & \\
\hline 4 & Dryops lutulentus (Erichson 1947) & $\bullet \bullet$ & $\bullet$ & $\bullet$ & - & & \\
\hline 5 & Dryops sulcipennis (Costa, 1883) & & & & $\bullet$ & & \\
\hline \multicolumn{8}{|c|}{ Dytiscidae } \\
\hline 6 & Agabus biguttatus (Olivier, 1795) & & & $\bullet$ & $\bullet$ & & \\
\hline 7 & Colymbetes piceus Klug, 1834 & & & $\bullet$ & $\bullet$ & & \\
\hline 8 & Colymbetes substrigatus Sharp, 1882 & & & $\bullet$ & $\bullet$ & & \\
\hline 9 & Copelatus antoniorum Hájek \& Brancucci, 2011 & $\bullet \bullet$ & & & $\bullet$ & & \\
\hline 10 & Copelatus atrosulcatus Régimbart, 1906 & & & & $\bullet$ & & \\
\hline 11 & Copelatus gestroi (Sharp, 1882) & $\bullet \bullet$ & & $\bullet$ & $\bullet$ & & \\
\hline 12 & Copelatus pulchellus (Klug, 1834) & & & $\bullet$ & $\bullet$ & & \\
\hline 13 & Cybister (Cybister) cephalotes Sharp, 1882 & & & $\bullet$ & $\bullet$ & & \\
\hline 14 & Cybister (Cybister) crassipes Sharp, 1882 & & & $\bullet$ & & & \\
\hline 15 & Cybister (Cybister) tripunctatus africanus Laporte, 1835 & $\bullet \bullet$ & & $\bullet$ & $\bullet$ & & \\
\hline 16 & Cybister (Cybister) tripunctatus lateralis (Fabricius, 1798) & $\bullet \bullet$ & $\bullet$ & & & & \\
\hline 17 & Cybister (Melanectes) vulneratus Klug, 1834 & $\bullet \bullet$ & $\bullet$ & $\bullet$ & $\bullet$ & $\bullet$ & \\
\hline 18 & Eretes griseus Fabricius, $1781^{(1)}$ & $\bullet$ & & & $\bullet$ & & \\
\hline 19 & Eretes sticticus (Linnaeus, 1767) & $\bullet \bullet$ & $\bullet$ & $\bullet$ & $\bullet$ & & $\bullet$ \\
\hline 20 & Glareadessus stocki Wewalka \& Biström, 1998 & $\bullet \bullet$ & $\bullet$ & & & & \\
\hline 21 & Hydaticus (Prodaticus) africanus (Rocchi, 1976) & $\bullet$ & & $\bullet$ & $\bullet$ & & \\
\hline 22 & Hydaticus (Prodaticus) arabicus Guignot, 1951 & & & & $\bullet$ & & \\
\hline 23 & Hydaticus (Prodaticus) decorus Klug, 1834 & & & • & - & & \\
\hline 24 & Hydaticus (Prodaticus) dorsiger Aubé, 1838 & & & $\bullet$ & $\bullet$ & & \\
\hline 25 & Hydaticus (Prodaticus) dregei Aubé, 1838 & & & $\bullet$ & $\bullet$ & & \\
\hline 26 & Hydaticus (Prodaticus) flavolineatus Boheman, 1848 & & & $\bullet$ & $\bullet$ & & \\
\hline 27 & Hydaticus (Prodaticus) histrio Clark, 1864 & $\bullet \bullet$ & $\bullet$ & $\bullet$ & $\bullet$ & & \\
\hline 28 & Hydaticus (Prodaticus) pictus (Sharp, 1882) & $\bullet \bullet$ & $\bullet$ & $\bullet$ & & & \\
\hline 29 & Hydaticus (Prodaticus) ponticus Sharp, 1882 & & & $\bullet$ & & & \\
\hline 30 & Hydaticus (Prodaticus) satoi dhofarensis Pederzani, 2003 & $\bullet$ & & & & & \\
\hline 31 & Hydaticus (Prodaticus) servillianus Aubé, 1838 & $\bullet \bullet$ & $\bullet$ & & - & & \\
\hline 32 & Hydroglyphus angularis (Klug, 1834) & $\bullet \bullet$ & $\bullet$ & $\bullet$ & $\bullet$ & & \\
\hline 33 & Hydroglyphus confusus (Klug, 1834) & $\bullet$ & & $\bullet$ & $\bullet$ & & \\
\hline 34 & Hydroglyphus farquharensis (Scott, 1912) & $\bullet \bullet$ & & & & & \\
\hline 35 & Hydroglyphus geminus (Fabricius, 1792) & & & $\bullet$ & & & \\
\hline 36 & Hydroglyphus gujaratensis (Vazirani, 1973) & $\bullet$ & & & & & \\
\hline 37 & Hydroglyphus hormuzensis Hájek \& Brancucci, 2011 & $\bullet \bullet$ & $\bullet$ & & & & \\
\hline 38 & Hydroglyphus infirmus (Boheman, 1848) & $\bullet$ & & $\bullet$ & $\bullet$ & & \\
\hline 39 & Hydroglyphus major (Sharp, 1882) & $\bullet$ & & $\bullet$ & $\bullet$ & & \\
\hline 40 & Hydroglyphus signatellus (Klug, 1834) & $\bullet \bullet$ & $\bullet$ & $\bullet$ & $\bullet$ & & \\
\hline 41 & Hydroglyphus sinuspersicus Hájek \& Wewalka, 2009 & $\bullet \bullet$ & $\bullet$ & & & & \\
\hline 42 & Hydroporus carli Wewalka, $1992^{(2)}$ & & & & $\bullet$ & & \\
\hline 43 & Hydrovarus aristidis Leprieur, 1879 & & & $\bullet$ & & & \\
\hline 44 & Hydrovatus acuminatus Motschulsky, 1860 & $\bullet$ & & $\bullet$ & $\mathrm{s}$ & & \\
\hline 45 & Hygrotus (Coelambus) confluens (Fabricius, 1787) & & $\bullet$ & $\bullet$ & $\bullet$ & & \\
\hline 46 & Hygrotus (Hygrotus) guineensis (Aubé, 1838) & & & $\bullet$ & $\bullet$ & & \\
\hline 47 & Hygrotus (Hygrotus) musicus (Klug, 1834) & & $\bullet$ & $\bullet$ & $\bullet$ & & \\
\hline 48 & Hygrotus (Hyphoporus) solieri (Aubé, 1838) & & & $\bullet$ & & & \\
\hline 49 & Hygrotus (Leptolambus) inscriptus (Sharp, 1882) & $\bullet$ & $\bullet$ & $\bullet$ & & & \\
\hline 50 & Hygrotus (Leptolambus) orthogrammus (Sharp, 1882) & & & $\bullet$ & & & \\
\hline 51 & Hyphydrus pictus Klug, 1834 & $\bullet \bullet$ & $\bullet$ & $\bullet$ & • & & \\
\hline 52 & Laccophilus inobservatus Biström, Nilsson \& Bergsten, 2015 & & & & $\bullet$ & & \\
\hline 53 & Laccophilus maindroni maindroni Régimbart, 1897 & $\bullet \bullet$ & $\bullet$ & & & & \\
\hline 54 & Laccophilus pictipennis Sharp, 1882 & $\bullet$ & & $\bullet$ & $\bullet$ & & \\
\hline 55 & Laccophilus poecilus Klug, 1834 & & & $\bullet$ & & & \\
\hline 56 & Laccophilus sharpi Régimbart, 1889 & & & $\bullet$ & $\bullet$ & & \\
\hline
\end{tabular}

(1) Eretes griseus was recorded from Oman in NILSSON \& HÁJEK (2018b), although we have not found precise records posterior to the revision by MILLER (2002).

(2) Recorded from Oman (without detailed data) by ShAVERDo et al. (2008) as Hydroporus inscitus Sharp, 1882, although the specimens from Yemen (without any record from Oman) were described as H. carli by WewALKa (1992). 


\begin{tabular}{|c|c|c|c|c|c|c|c|}
\hline No & species & Oman & UAE & S Arabia & Yemen & Bahrain & Qatar \\
\hline 57 & Laccophilus sordidus Sharp, 1882 & & & $\bullet$ & $\bullet$ & & \\
\hline 58 & Laccophilus sublineatus Sharp, $1882^{(3)}$ & & & $\bullet$ & $\bullet$ & & \\
\hline 59 & Methles cribratellus (Fairmaire, 1880) & & & $\bullet$ & & & \\
\hline 60 & Nebrioporus banajai (Brancucci, 1980) & & & $\bullet$ & & & \\
\hline 61 & Nebrioporus crotchi (Preudhomme de Borre, 1871) & & & $\bullet$ & & & \\
\hline 62 & Nebrioporus insignis (Klug, 1834) & & & $\bullet$ & $\bullet$ & & \\
\hline 63 & Nebrioporus lanceolatus (Walker, 1871) & & & $\bullet$ & & & \\
\hline 64 & Nebrioporus mascatensis (Régimbart, 1897) & $\bullet \bullet$ & $\bullet$ & & & & \\
\hline 65 & Nebrioporus millingeni (J. Balfour-Browne, 1951) & & & & $\bullet$ & & \\
\hline 66 & Nebrioporus seriatus (Sharp, 1882) & & & $\bullet$ & $\bullet$ & & \\
\hline 67 & Rhantus includens (Walker, 1871) & & & $\bullet$ & $\bullet$ & & \\
\hline 68 & Rhantus suturalis (W. S. Macleay, 1825) & & & $\bullet$ & & & \\
\hline 69 & Uvarus occultus (Sharp, 1882) & & & $\bullet$ & & & \\
\hline 70 & Uvarus peringueyi (Régimbart, 1895) & & & & $\bullet$ & & \\
\hline 71 & Yola bicristata (Sharp, 1882) & & & $\bullet$ & $\bullet$ & & \\
\hline 72 & Yola buettikeri Brancucci, 1985 & & & $\bullet$ & $\bullet$ & & \\
\hline 73 & Yola darfurensis J. Balfour-Browne, 1947 & & & & $\bullet$ & & \\
\hline 74 & Yola enigmatica Omer-Cooper, 1954 & & & $\bullet$ & $\bullet$ & & \\
\hline 75 & Yola porcata (Klug, 1834) & & & $\bullet$ & & & \\
\hline 76 & Yolina insignis (Sharp, 1882) & $\bullet$ & & $\bullet$ & $\bullet$ & & \\
\hline \multicolumn{8}{|c|}{ Elmidae } \\
\hline 77 & Potamodytes subrotundatus Pic, 1939 & & $\bullet$ & $\bullet$ & $\bullet$ & & \\
\hline 78 & Stenelmis spp. & & $\bullet$ & $\bullet$ & & & \\
\hline \multicolumn{8}{|c|}{ Georissidae } \\
\hline 79 & Georissus (Neogeorissus) chameleo Fikáček \& Trávníček, 2009 & $\bullet \bullet$ & $\bullet$ & & & & \\
\hline \multicolumn{8}{|c|}{ Gyrinidae } \\
\hline 80 & Aulonogyrus (Afrogyrus) ater Brinck, 1955 & & & & $\bullet$ & & \\
\hline 81 & Aulonogyrus (Aulonogyrus) concinnus Klug, 1834 & & & $\bullet$ & & & \\
\hline 82 & Dineutus (Cyclous) aereus (Klug, 1834) & $\bullet \bullet$ & $\bullet$ & $\bullet$ & $\bullet$ & $\bullet$ & \\
\hline 83 & Dineutus (Cyclous) arabicus Régimbart, 1907 & & & & $\bullet$ & & \\
\hline 84 & Dineutus (Cyclous) grandis Klug, 1834 & & & $\bullet$ & $\bullet$ & & \\
\hline 85 & Dineutus (Cyclous) subspinosus (Klug, 1834) & $\bullet \bullet$ & & & & & \\
\hline 86 & Gyrinus (Gyrinus) distinctus Aubé, 1838 & & $\bullet$ & & & & \\
\hline 87 & Gyrinus (Gyrinus) luctuosus Régimbart, 1883 & & & $\bullet$ & $\bullet$ & & \\
\hline 88 & Gyrinus (Gyrinus) urinator Illiger, 1807 & & & $\bullet$ & & & \\
\hline \multicolumn{8}{|c|}{ Haliplidae } \\
\hline 89 & Haliplus (Neohaliplus) lineatocollis Marsham, 1802 & & & $\bullet$ & $\bullet$ & & \\
\hline \multicolumn{8}{|c|}{ Helophoridae } \\
\hline 90 & Helophorus (Helophorus) syriacus Kuwert, 1885 & & & $\bullet$ & & & \\
\hline 91 & Helophorus (Rhopalohelophorus) angustatus Motschulsky, 1860 & & $\bullet$ & $\bullet$ & & & \\
\hline 92 & Helophorus (Rhopalohelophorus) mervensis A. P. Semenov, 1900 & & & $\bullet$ & $\bullet$ & & \\
\hline \multicolumn{8}{|c|}{ Heteroceridae } \\
\hline 93 & Augyles flavidus (Rossi, 1794) & $\bullet \bullet$ & $\bullet$ & & & & \\
\hline 94 & Augyles turanicus (Reitter, 1887) & & $\bullet$ & & & & \\
\hline 95 & Heterocerus harteni Mascagni, 2009 & & $\bullet$ & & & & \\
\hline 96 & Heterocerus magnus Mamitza, 1933 & $\bullet \bullet$ & $\bullet$ & & & & \\
\hline 97 & Heterocerus mus Charpentier, 1965 & & $\bullet$ & & & & \\
\hline \multicolumn{8}{|c|}{ Hydraenidae } \\
\hline 98 & Hydraena (Hydraena) gattolliati Jäch \& Delgado, 2010 & $\bullet \bullet$ & $\bullet$ & & & & \\
\hline 99 & Hydraena (Hydraena) naja sp. nov. & $\bullet \bullet$ & & & & & \\
\hline 100 & Hydraena (Phothydraena) putearius Jäch \& Díaz, 2000 & $\bullet \bullet$ & $\bullet$ & & & & \\
\hline 101 & Hydraena (Hydraenopsis) arabica Balfour-Borwne, 1951 & $\bullet$ & & $\bullet$ & $\bullet$ & & \\
\hline 102 & Hydraena (Hydraenopsis) quadricollis Wollaston, 1864 & $\bullet \bullet$ & & & & & \\
\hline 103 & Limnebius (Bilimneus) arabicus Balfour-Browne, 1951 & & & & $\bullet$ & & \\
\hline 104 & Limnebius (Bilimneus) fontinalis Balfour-Browne, 1951 & & & $\bullet$ & $\bullet$ & & \\
\hline 105 & Limnebius (Bilimneus) pararabicus Jäch \& Delgado, 2010 & & $\bullet$ & & & & \\
\hline 106 & Limnebius (Bilimneus) wewalkai Jäch \& Delgado, 2010 & $\bullet \bullet$ & $\bullet$ & & & & \\
\hline 107 & Ochthebius (Ochthebius) alhajarensis sp. nov. & $\bullet \bullet$ & & & & & \\
\hline 108 & Ochthebius (Ochthebius) andraei andraei Breit, 1920 & & & $\bullet$ & & & \\
\hline 109 & Ochthebius (Ochthebius) arabicus Jäch, 1992 & & & $\bullet$ & & & \\
\hline 110 & Ochthebius (Ochthebius) bernard sp. nov. & $\bullet \bullet$ & & & & & \\
\hline 111 & Ochthebius (Ochthebius) burjkhalifa Jäch \& Delgado, 2014 & & $\bullet$ & & & & \\
\hline
\end{tabular}

(3) Recorded from Oman by BRANCUCCI (1983) without detailed data. 


\begin{tabular}{|c|c|c|c|c|c|c|c|}
\hline No & species & Oman & UAE & S Arabia & Yemen & Bahrain & Qatar \\
\hline 112 & Ochthebius (Ochthebius) cameroni Balfour-Browne, 1951 & & & & $\bullet$ & & \\
\hline 113 & Ochthebius (Ochthebius) despoliatus Jäch \& Delgado, 2014 & & $\bullet$ & & & & \\
\hline 114 & Ochthebius (Ochthebius) harteni Jäch \& Delgado, 2010 & $\bullet \bullet$ & $\bullet$ & & & & \\
\hline 115 & Ochthebius (Ochthebius) innexus Balfour-Browne, 1951 & & & $\bullet$ & $\bullet$ & & \\
\hline 116 & Ochthebius (Ochthebius) mahmoodi Jäch \& Delgado, 2014 & $\bullet \bullet$ & $\bullet$ & & & & \\
\hline 117 & Ochthebius (Ochthebius) meridionalis Rey, 1885 & & & - & & & \\
\hline 118 & Ochthebius (Ochthebius) micans Balfour-Browne, 1951 & & & $\bullet$ & $\bullet$ & & \\
\hline 119 & Ochthebius (Ochthebius) monseti Jäch \& Delgado, 2010 & $\bullet \bullet$ & $\bullet$ & & & & \\
\hline 120 & Ochthebius (Ochthebius) patergazellae Jäch \& Delgado, 2010 & & $\bullet$ & & & & \\
\hline 121 & Ochthebius (Ochthebius) quadrifoveolatus Wollaston, 1854 & & & $\bullet$ & & & \\
\hline 122 & Ochthebius (Ochthebius) ragusae Kuwert, 1887 & & & $\bullet$ & & & \\
\hline 123 & Ochthebius (Ochthebius) thermalis Janssens, 1965 & & & $\bullet$ & & & \\
\hline 124 & Ochthebius (Ochthebius) wurayah Jäch \& Delgado, 2010 & $\bullet \bullet$ & $\bullet$ & & & & \\
\hline 125 & Ochthebius (Ochthebius) zugmayeri Kniž, 1909 & & $\bullet$ & $\bullet$ & & & \\
\hline \multicolumn{8}{|c|}{ Hydrophilidae } \\
\hline 126 & Agraphydrus (Agraphydrus) elongatus sp. nov. & $\bullet \bullet$ & $\bullet \bullet$ & & & & \\
\hline 127 & Agraphydrus (Agraphydrus) minutissimus (Kuwert, 1890) & $\bullet \bullet$ & $\bullet$ & $\bullet$ & $\bullet$ & & \\
\hline 128 & Allocotocerus striatopunctatus (Laporte, 1840) & & & $\bullet$ & & & \\
\hline 129 & Arabhydrus gallagheri Hebauer, 1997 & $\bullet \bullet$ & $\bullet$ & & & & \\
\hline 130 & Berosus (Berosus) fuscostriatus Fairmaire, 1892 & $\bullet \bullet$ & $\bullet$ & $\bullet$ & $\bullet$ & & \\
\hline 131 & Berosus (Berosus) insolitus d'Orchymont, 1937 & & & $\bullet$ & & & \\
\hline 132 & Berosus (Berosus) nigriceps (Fabricius, 1801) & $\bullet \bullet$ & $\bullet$ & $\bullet$ & $\bullet$ & & \\
\hline 133 & Berosus (Berosus) problematicus Schödl, 1993 & & & & $\bullet$ & & \\
\hline 134 & Berosus (Berosus) pulchellus W. S. Macleay, 1825 & & & $\bullet$ & & & \\
\hline 135 & Berosus (Berosus) rubiginosus Kuwert, 1890 & $\bullet \bullet$ & $\bullet$ & $\bullet$ & $\bullet$ & & \\
\hline 136 & Berosus (Enoplurus) chinensis Knisch, 1922 & & $\bullet$ & & & & \\
\hline 137 & Cercyon (Cercyon) deserticola Fikáček, Gentili \& Short, 2010 & & $\bullet$ & & & & \\
\hline 138 & Cercyon (Cercyon) nigriceps Marsham, 1802 & & & $\bullet$ & $\bullet$ & & \\
\hline 139 & Cercyon (Cercyon) quisquilius (Linnaeus, 1760) & & $\bullet$ & $\bullet$ & & & \\
\hline 140 & Cercyon (Clynocercion) lineolatus Motschulsky, 1863 & & $\bullet$ & & & & \\
\hline 141 & Cercyon (Paracycreon) subsolanus Balfour-Browne, 1939 & & & $\bullet$ & & & \\
\hline 142 & Coelostoma (Holocoelostoma) stultum (Walker, 1858) & $\bullet \bullet$ & $\bullet$ & $\bullet$ & $\bullet$ & & \\
\hline 143 & Coelostoma (Lachnocoelostoma) horni (Régimbart, 1902) & $\bullet$ & & $\bullet$ & $\bullet$ & & \\
\hline 144 & Coelostoma (Lachnocoelostoma) transcaspicum Reitter, 1906 & $\bullet \bullet$ & $\bullet$ & $\bullet$ & & & \\
\hline 145 & Cryptopleurum ferrugineum Motschulsky, 1863 & & & $\bullet$ & & & \\
\hline 146 & Dactylosternum abdominale (Fabricius, 1792) & & - & & - & & \\
\hline 147 & Dactylosternum arabicum Balfour-Browne, 1951 & & & & $\bullet$ & & \\
\hline 148 & Emmidolium excavatum d'Orchymont, 1937 & & $\bullet$ & & & & \\
\hline 149 & Enochrus (Lumetus) ater (Kuwert, 1888) & $\bullet \bullet$ & & $\bullet$ & & & \\
\hline 150 & Enochrus (Lumetus) politus (Küster, 1849) & $\bullet \bullet$ & $\bullet$ & & & & \\
\hline 151 & Enochrus (Lumetus) cf. quadrinotatus (Guillebeau, 1896) & $\bullet$ & & & & & \\
\hline 152 & Enochrus (Lumetus) segmentinotatus Kuwert, 1888 & & $\bullet$ & $\bullet$ & & & \\
\hline 153 & Enochrus (Lumetus) sinuatus d'Orchymont, 1937 & & $\bullet$ & & & & \\
\hline 154 & Enochrus (Methydrus) circumductus Régimbart, 1905 & & & & $\bullet$ & & \\
\hline 155 & Enochrus (Methydrus) esuriens Walker, 1858 & & & $\bullet$ & & & \\
\hline 156 & Enochrus (Methydrus) hesperidum Sharp, 1870 & & & $\bullet$ & $\bullet$ & & \\
\hline 157 & Enochrus (Methydrus) latus Kuwert, 1888 & & & $\bullet$ & & & \\
\hline 158 & Enochrus (Methydrus) cf. tetraspilus Régimbart, 1903 & $\bullet \bullet$ & $\bullet$ & & $\bullet$ & & \\
\hline 159 & Helochares (Helochares) pallens W. S. Macleay, 1825 & & & $\bullet$ & $\bullet$ & & \\
\hline 160 & Helochares (Hydrobaticus) andreinii d'Orchymont, 1939 & $\bullet$ & & $\bullet$ & $\bullet$ & & \\
\hline 161 & Helochares (Hydrobaticus) crenulatoides d'Orchymont, 1943 & $\bullet \bullet$ & $\bullet$ & & & & \\
\hline 162 & Hydrochara flavipalpis (Boheman, 1851) & $\bullet$ & & $\bullet$ & $\bullet$ & & \\
\hline 163 & Hydrophilus (Hydrophilus) senegalensis Percheron, 1835 & & & $\bullet$ & $\bullet$ & & \\
\hline 164 & Hydrophilus (Temnopterus) aculeatus (Solier, 1834) & $\bullet$ & & $\bullet$ & $\bullet$ & & \\
\hline 165 & Laccobius (Cyclolaccobius) arabicus Gentili, 1980 & & & $\bullet$ & $\bullet$ & & \\
\hline 166 & Laccobius (Dimorpholaccobius) eremita Gentili, 1989 & & & $\bullet$ & & & \\
\hline 167 & Laccobius (Hydroxenus) leucaspis Kiesenwetter, 1870 & $\bullet \bullet$ & & $\bullet$ & & & \\
\hline 168 & Laccobius (Hydroxenus) subpictus erlangeri Régimbart, 1905 & & & $\bullet$ & $\bullet$ & & \\
\hline 169 & Laccobius (Microlaccobius) algiricus Hansen, 1999 & & & $\bullet$ & & & \\
\hline 170 & Laccobius (Microlaccobius) eximius Kuwert, 1890 & & & $\bullet$ & $\bullet$ & & \\
\hline 171 & Laccobius (Microlaccobius) harteni Fikáček, Gentili \& Short, 2010 & & $\bullet$ & & & & \\
\hline 172 & Laccobius (Microlaccobius) minor Wollaston, 1867 & & & $\bullet$ & $\bullet$ & & \\
\hline
\end{tabular}




\begin{tabular}{|c|c|c|c|c|c|c|c|}
\hline No & species & Oman & UAE & S Arabia & Yemen & Bahrain & Qatar \\
\hline 173 & Laccobius (Microlaccobius) orsenigoi Gentili, 1980 & $\bullet \bullet$ & $\bullet$ & & & & \\
\hline 174 & Laccobius (Microlaccobius) praecipuus Kuwert, 1890 & $\bullet \bullet$ & • & $\bullet$ & - & & $\bullet$ \\
\hline 175 & Pachysternum brunneum Balfour-Browne, 1951 & & & & $\bullet$ & & \\
\hline 176 & Paracymus relaxus Rey, 1884 & $\bullet \bullet$ & $\bullet$ & $\bullet$ & $\bullet$ & & \\
\hline 177 & Regimbartia attenuata (Fabricius, 1801) & $\bullet$ & $\bullet$ & & $\bullet$ & & \\
\hline 178 & Sphaeridium caffrum Laporte, 1840 & & & & $\bullet$ & & \\
\hline 179 & Sphaeridium exile Boheman, 1851 & & & & - & & \\
\hline 180 & Sphaeridium quinquemaculatum Fabricius, 1798 & & & $\bullet$ & & & \\
\hline 181 & Sphaeridium senegalense Laporte, 1840 & & & & $\bullet$ & & \\
\hline 182 & Sternolophus decens Zaitzev, 1909 & $\bullet \bullet$ & $\bullet$ & $\bullet$ & $\bullet$ & & \\
\hline 183 & Sternolophus elongatus Schaufuss, 1883 & & & $\bullet$ & $\bullet$ & & \\
\hline 184 & Sternolophus solieri Laporte, 1840 & & & $\bullet$ & - & & \\
\hline 185 & Thysanarthria brittoni Balfour-Browne, 1951 & & & & $\bullet$ & & \\
\hline 186 & Thysanarthria wadicola Fikáček \& Liu, 2019 & $\bullet \bullet$ & $\bullet$ & & & & \\
\hline \multicolumn{8}{|c|}{ Limnichidae } \\
\hline 187 & Byrrhinus helicophallus Hernando \& Ribera, 2014 & & & & $\bullet$ & & \\
\hline 188 & Limnichus arabicus Hernando \& Ribera, 2014 & & & & $\bullet$ & & \\
\hline 189 & Pelochares sabaeanus Hernando \& Ribera, 2014 & & & & $\bullet$ & & \\
\hline 190 & Pelochares sinbad Hernando \& Ribera, 2014 & $\bullet \bullet$ & $\bullet$ & & & & \\
\hline \multicolumn{8}{|c|}{ Noteridae } \\
\hline 191 & Canthydrus arabicus Sharp, 1882 & & & $\bullet$ & & & \\
\hline 192 & Canthydrus luctuosus Aubé, 1838 & & & $\bullet$ & & & \\
\hline \multirow[t]{2}{*}{193} & Canthydrus notula (Erichson, 1843) & - & & & - & & \\
\hline & Total number of species & 73 & 67 & 116 & 99 & 2 & 2 \\
\hline
\end{tabular}

\section{Heterocerus magnus Mamitza, 1933}

Published records. SKALICKÝ (2004, 2014).

Material examined. Loc. 1: 1 spec. (remains); Loc. 2: 1 spec.; Loc. 8: 3 spec.; Loc. 9: 6 spec. (plus larvae and pupae); Loc. 11: 4 spec. (plus 2 larvae); Loc. 12: 12 spec. (plus larva).

\section{Limnichidae}

\section{Pelochares sinbad Hernando \& Ribera, 2014}

\section{Published records. HERNANDO \& RiBERA (2014).}

Material examined. Loc. 2: 1 spec.: Loc. 8: 6 spec. (paratypes, one used for DNA extraction, voucher No. IBE-RA123); Loc. 10: $1 \mathrm{spec}$ (paratype); Loc. 11: 10 spec. (holotype, paratypes); Loc. 12: 12 spec. (paratypes); Loc. 14: 1 \%

Notes. The species was described with the specimens reported here and material from the UAE.

\section{Discussion}

With 73 recorded species (Table 2), the fauna of aquatic Coleoptera of Oman is relatively poor (a similar, or higher number could easily be collected in many single localities in the western Palaearctic, e.g. Ribera \& AguILERA 1996), but it is similar to that of neighbouring areas (Table 2). Some families common in the Palaearctic are absent from Oman, although, at least for those present elsewhere in the Arabian Peninsula, there is the possibility that the absence is only due to lack of sampling. Thus, further explorations are likely to increase substantially the number of species known from Oman. Obvious candidates are species of some families still not recorded but present in neighbouring areas, such as e.g. Haliplidae, Helophoridae or Elmidae. Haliplus lineatocollis Marsham, 1802 has been recorded from Yemen and Saudi Arabia, several species of Helophorus Fabricius, 1775 are known from Yemen, Saudi Arabia and the United Arab Emi- rates, and there is one Elmidae, Potamodytes subrotundatus Pic, 1939, also recorded from these three countries (JÄCH 1988, MASCAGNI 2009c, JäCH et al. 2016; Table 2). Of other families there are no records in the Arabian Peninsula (e.g. Hydrochidae, Spercheidae), but their presence cannot yet be discarded.

Within Oman, the Al-Hajar mountains in the north have proved to be one of the richest areas, both in total number of species and in the number of endemics. This mountain range includes the highest peak in the country, the Jebel Al-Akhdar with just over 3,000 m. Although altitudinal gradients at this latitude are far less pronounced than in temperate areas, the presence of different types of permanent and temporary habitats, as well as the long-term isolation, are likely some of the reasons of its relative high diversity. As an example, in the source of the wadi Bani Awf (our locality No. 4) we found six species of Hydraenidae: three new to science, for which this is the type locality (Hydraena naja sp. nov., Ochthebius alhajarensis sp. nov. and $O$. bernard sp. nov.), and three endemic to Oman and UAE. (H. putearius, H. gattolliati and $O$. wurayah). The Al-Hajar mountains have been also recently identified as a centre of endemism for other groups, specially reptiles, mostly by the recognition of cryptic lineages (e.g. Garcia-Porta et al. 2017; Mendes et al. 2017). The aquatic beetle fauna of the Al-Hajar mountains has a predominantly Palaearctic origin, and seems to be closely related to the fauna of south Iran. Thus, two of the species newly described here and found only on these mountains are closely related to Iranian species (H. naja sp. nov. and O. bernard sp. nov.), although some of the lowland species with clear Ethiopian affinities can also be found at high altitude (e.g. Hydroglyphus sinuspersicus or $H$. hormuzensis). At lower altitudes the fauna is of a more varied origin, with some species of Palaearctic affinities but others within lineages of mostly tropical distribution. 


\section{Acknowledgements}

We thank Salvador Carranza (IBE, Barcelona) and other members of his laboratory for providing specimens for study, as well as valuable comments and advice on the habitats and fauna of Oman, and Hans Fery (Berlin), Jiří Hájek and Martin Fikáček (Prague) and Manfred Jäch (Vienna) for comments on the manuscript and their help and support in multiple ways. We especially thank Albrecht Komarek (Vienna) for his help in the study of Agraphydrus elongatus sp. nov., and for providing specimens from the UAE and unpublished information from his ongoing revision of the genus. We also thank Rocío Alonso and Anabela Cardoso (IBE) for laboratory work, and funding from projects CGL2007-61665, CGL2013-48950-C2-1-P and CGL2016-76705-P (AEI/FEDER, UE).

Table 3. Species found in the 14 sampled localities in north Oman (see Table 1 for details on the localities).

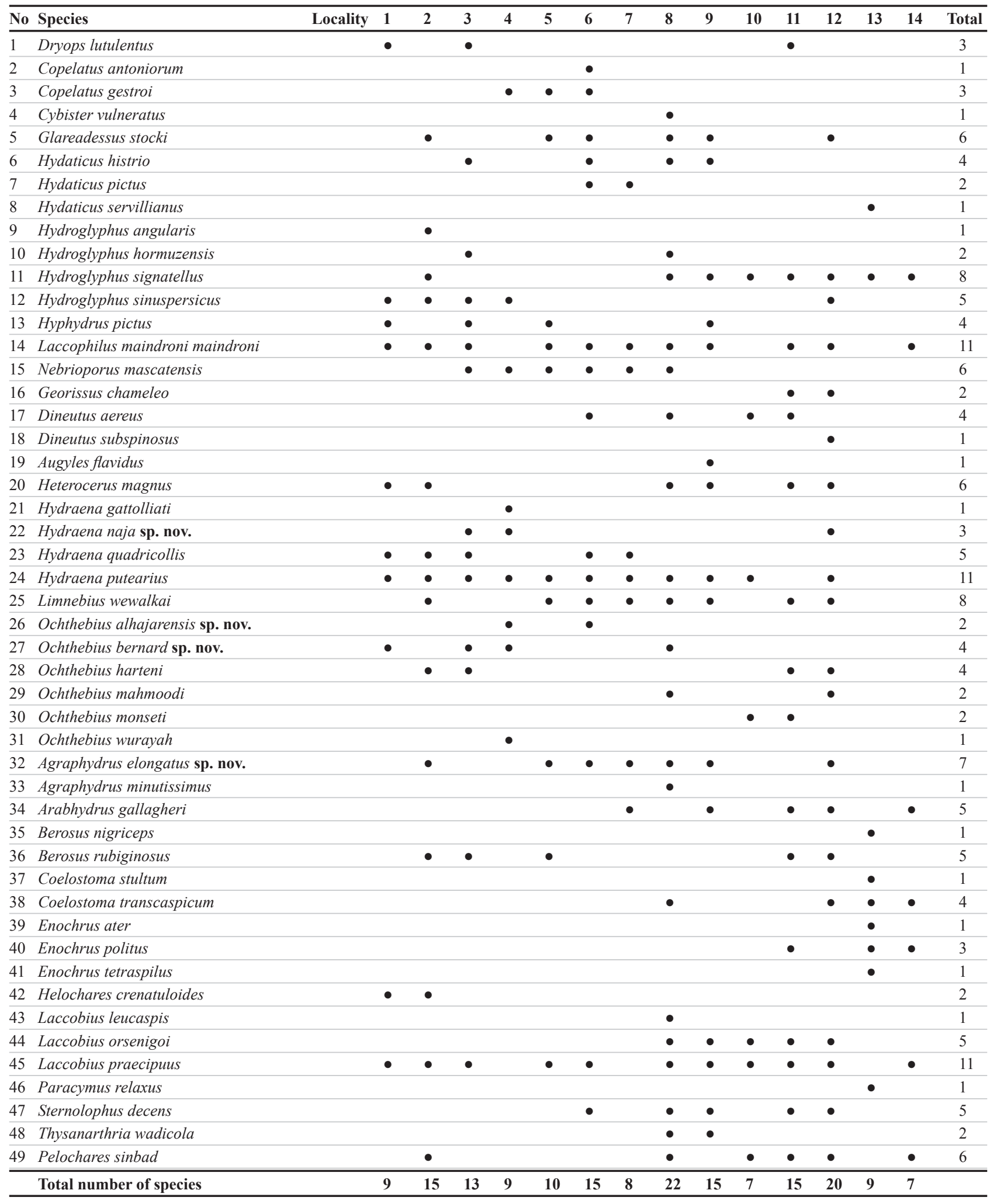




\section{References}

ABELLÁN P. \& RIBERA I. 2011: Geographic location and phylogeny are the main determinants of the size of the geographical range in aquatic beetles. BMC Evolutionary Biology 11(344): 1-15.

ABELLÁN P., SÁNCHEZ-FERNÁNDEZ D., PICAZO F., MILLÁN A., LOBO J. M. \& RIBERA I. 2013: Preserving the evolutionary history of freshwater biota in Iberian National Parks. Biological Conservation 162: 116-126.

ALARIE Y. \& WEWALKA G. 2001: Description of the mature larva of Glareadessus stocki Wewalka \& Bistrom (Coleoptera: Dytiscidae), a stygobiontic Bidessini from the Persian Gulf Region. Coleopterists Bulletin 55: 144-151.

ARRIBAS P., ANDÚJAR C., ABELLÁN P., VELASCO J., MILLÁN A. \& RIBERA I. 2014: Tempo and mode of the multiple origins of salinity tolerance in a water beetle lineage. Molecular Ecology 23: $360-373$.

BALFOUR-BROWNE J. 1951: Coleoptera: Haliplidae, Dytiscidae, Gyrinidae, Hydraenidae, Hydrophilidae. Expedition to South-West Arabia 1(16): 179-220 + pls 10, 11

BERTHELEMY C., KADDOURI A. \& RICHOUX P. 1991: Revision of the genus Hydraena Kugelann, 1794 from North Africa (Coleoptera: Hydraenidae). Elytron 5: 181-213.

BEZDĚK J. \& HÁJEK J. 2017: Insect biodiversity of the Socotra Archipelago - underlined and counted. Acta Entomologica Musei Nationalis Pragae 57 (Supplementum): 1-39.

BISTRÖM O. 1986: Review of the genus Hydroglyphus Motschulsky (=Guignotus Houlbert) in Africa (Coleoptera, Dytiscidae). Acta Zoologica Fennica 182: 1-53.

BRANCUCCI M. 1979: Insects of Saudi Arabia. Coleoptera: Fam Haliplidae, Dytiscidae, Gyrinidae. Fauna of Saudi Arabia 1: 156-161.

BRANCUCCI M. 1980: Insects of Saudi Arabia. Coleoptera: Fam. Haliplidae, Dytiscidae, Gyrinidae. Part 2. Fauna of Saudi Arabia 2: $102-111$.

BRANCUCCI M. 1981: Insects of Saudi Arabia. Coleoptera: Fam. Dytiscidae (Part 3). Fauna of Saudi Arabia 3: 227-230.

BRANCUCCI M. 1983: Révision des espèces est-paléarctiques, orientales et australiennes du genre Laccophilus (Col. Dytiscidae). Entomologische Arbeiten aus dem Museum G. Frey 31-32: 241-426.

BRANCUCCI M. 1985: Insects of Saudi Arabia. Coleoptera: Fam. Haliplidae, Noteridae, Dytiscidae, Gyrinidae (Part 4). Fauna of Saudi Arabia 6: 229-242.

DELÈVE J. 1970: Contribution à la faune de l'Iran, 19, Coléoptères Dryopoidea. Annales de la Société Entomologique de France (Nouvelle Série) 6: 701-703.

FERRO G. 1984: Hydraenidae nuovi ed interessanti del Museo di Storia Naturale di Praga. III contributo (Coleoptera Hydraenidae). Bulletin et Annales de la Société Royale Belge d'Entomologie 120: 61-71.

FERY H. \& RIBERA I. 2018: Phylogeny and taxonomic revision of Deronectina Galewski, 1992 (Coleoptera: Dytiscidae: Hydroporinae: Hydroporini). Zootaxa 4474: 1-104.

FIKÁČEK M. 2009: Order Coleoptera, family Helophoridae. Pp. 142-144. In: HARTEN A. VAN (ed.): Arthropod Fauna of the United Arab Emirates. Volume 2. Multiply Marketing Consultancy Services, Abu Dhabi, 786 pp.

FIKÁČEK M. \& LIU H.-C. 2019: A review of the genus Thysanarthria and comments on its relationships to Chaetarthria (Hydrophilidae: Chaetarthriini). Acta Entomologica Musei Nationalis Pragae 58(1): 229-252.

FIKÁČEK M., GENTILI E. \& SHORT A. E. Z. 2010: Order Coleoptera, Family Hydrophilidae. Pp. 135-165. In: HARTEN A. vAN (ed.): Arthropod Fauna of the United Arab Emirates. Volume 3. Multiply Marketing Consultancy Services, Abu Dhabi, 700 pp.

FIKÁČEK M. \& TRÁVNÍČEK D. 2009: Order Coleoptera, family Georissidae. Pp. 145-148. In: HARTEN A. vAN (ed.): Arthropod Fauna of the United Arab Emirates. Volume 2. Multiply Marketing Consultancy Services, Abu Dhabi, 786 pp.

GARCIA-PORTA J., SIMÓ-RIUDALBAS M., ROBINSON M. \& CARRANZA S. 2017: Diversification in arid mountains: biogeography and cryptic diversity of Pristurus rupestris rupestris in Arabia. Journal of Biogeography 44: 1694-1704.
GENTILI E. 1989: The Laccobius (Coleoptera, Hydrophilidae) of the Arabian Peninsula and Sinai. Fauna of Saudi Arabia 10: 95-102.

HÁJEK J. 2011: Order Coleoptera, Family Gyrinidae. Pp. 123-125. In: HARTEN A. VAN (ed.): Arthropod Fauna of the United Arab Emirates. Volume 4. Multiply Marketing Consultancy Services, Abu Dhabi, $832 \mathrm{pp}$

HÁJEK J. \& BRANCUCCI M. 2011: Order Coleoptera, Family Dytiscidae. Pp. 126-143. In: HARTEN A. vAN (ed.): Arthropod Fauna of the United Arab Emirates. Volume 4. Multiply Marketing Consultancy Services, Abu Dhabi, 832 pp.

HÁJEK J. \& REITER A. 2014: Adephagous water beetles (Coleoptera: Gyrinidae, Haliplidae, Noteridae, Dytiscidae) of Yemen and Dhofar region (Oman) with description of a new Hyphydrus from Socotra Island. Acta Entomologica Musei Nationalis Pragae 54: 63-99.

HÁJEK J. \& WEWALKA G. 2009: New and little known species of Hydroglyphus (Coleoptera: Dytiscidae) from Arabia and adjacent areas. Acta Entomologica Musei Nationalis Pragae 49: 93-102.

HEBAUER F. 1997: Annotated checklist of the Hydrophilidae and Helophoridae (Insecta: Coleoptera) of the Arabian Peninsula with a description of a new genus and species. Fauna of Saudi Arabia 16: $255-276$.

HEBAUER F. 2001: The species of the genus Thysanarthria d'Orchymont, 1926 (Coleoptera, Hydrophilidae). Beiträge zur Entomologie 51: $393-400$.

HERNANDO C. \& RIBERA I. 2014: The Limnichidae of the Arabian Peninsula and the Island of Socotra (Coleoptera). Acta Entomologica Musei Nationalis Pragae 54 (Supplemetum): 173-189.

HINTON H. E. 1948: 11. Coleoptera: Dryopidae and Elmidae. British Museum Expedition to South-West Arabia 1: 133-140.

JÄCH M. A. 1988: Elmidae (Coleoptera) of Saudi Arabia. Fauna of Saudi Arabia 9: 39-41.

JÄCH M. A. 1989: Revision of the Palearctic species of the genus Ochthebius Leach 1. The so-called subgenus "Bothochius" (Hydraenidae, Coleoptera). Koleopterologische Rundschau 59: 95-126.

JÄCH M. A. 1992: New and little known Palearctic species of the genus Hydraena (s. 1.) Kugelann (Coleoptera: Hydraenidae). Koleopterologische Rundschau 62: 77-125.

JÄCH M. A. \& DELGADO J. A. 2010: Order Coleoptera, family Hydraenidae. Pp. 173-194. In: HARTEN A. vAN (ed.): Arthropod Fauna of the United Arab Emirates. Volume 3. Multiply Marketing Consultancy Services, Abu Dhabi, 700 pp.

JÄCH M. A. \& DELGADO J. A. 2014: Order Coleoptera, family Hydraenidae. An update of the hydraenid fauna of the United Arab Emirates. Pp. 254-267. In: HARTEN A. vAN (ed.): Arthropod Fauna of the United Arab Emirates. Volume 5. Multiply Marketing Consultancy Services, Abu Dhabi, 744 pp.

JÄCH M. A. \& DELGADO J. A. 2017: Hydraenidae of Djibouti, with description of two new species (Coleoptera: Hydraenidae). Koleopterologische Rundschau 87: 51-84.

JÄCH M. A. \& DÍAZ J. A. 2000: Descriptions of eight new species of Hydraena (Coleoptera: Hydraenidae). Entomological Problems 31: 41-58.

JÄCH M. A., KODADA J., BROJER M., SHEPARD W. D. \& ČIAMPOR F. Jr. 2016: World Catalogue of Insects, Volume 14. Coleoptera: Elmidae and Protelmidae. Leiden, Brill, $318 \mathrm{pp}$.

JÄCH M. A. \& SKALE A. 2015: Family Hydraenidae. Pp. 130-162. In: LÖBL I. \& LÖBL D. (eds): Catalogue of Palaearctic Coleoptera. Volume 2/1, Revised and updated edition. Hydrophiloidea-Staphylinoidea. Brill, Leiden, 900 pp.

MASCAGNI A. 2009a: Order Coleoptera, family Dryopidae. Pp. 149-150. In: HARTEN A. VAN (ed.): Arthropod Fauna of the United Arab Emirates. Volume 2. Multiply Marketing Consultancy Services, Abu Dhabi, 786 pp.

MASCAGNI A. 2009b: Order Coleoptera, family Heteroceridae. Pp. 154-158. In: HARTEN A. VAN (ed.): Arthropod Fauna of the United Arab Emirates. Volume 2. Multiply Marketing Consultancy Services, Abu Dhabi, 786 pp.

MASCAGNI A. 2009c: Order Coleoptera, family Elmidae. Pp. 151-153. In: HARTEN A. vAN (ed.): Arthropod Fauna of the United Arab Emirates. Volume 2. Multiply Marketing Consultancy Services, Abu Dhabi, $786 \mathrm{pp}$. 
MASCAGNI A. 2014: The Variegated Mud-Loving Beetles of Europe (first part) (Coleoptera: Heteroceridae). Onychium 10 [2013]: 78-118.

MASCAGNI A., JÄCH M. A., OSTOVAN H. \& GHAHARI H. 2016 : Annotated checklist of Dryopidae and Heteroceridae (Coleoptera: Byrrhoidea) of Iran. Zootaxa 4144: 354-364.

MENDES J., SALVI D., HARRIS D. J., ELS J. \& CARRANZA S. 2017: Hidden in the Arabian Mountains: Multilocus phylogeny reveals cryptic diversity in the endemic Omanosaura lizards. Journal of Zoological Systematics and Evolutionary Research 56: 395-407.

MILLER K. B. 2002: Revision of the genus Eretes Laporte, 1833 (Coleoptera: Dytiscidae). Aquatic Insects 24: 247-272.

NASSERZADEH H. \& KOMAREK A. 2017: Taxonomic revision of the water scavenger beetle genus Sternolophus Solier, 1834 (Coleoptera: Hydrophilidae). Zootaxa 4282: 201-254.

NILSSON A. N. \& HÁJEK J. 2018a: A world catalogue of the family Dytiscidae (Coleoptera, Adephaga). Internet version 31.I.2018, 304 pp. Available from: http://www.waterbeetles.eu (accessed November 2018).

NILSSONA. N. \& HÁJEK J. 2018b: Catalogue of Palaearctic Dytiscidae (Coleoptera). Internet Version 31.I.2018, 88 pp. Available from: http:// www.waterbeetles.eu (accessed November 2018).

ORCHYMONT A. D’ 1936: Notes sur quelques espèces du genre Laccobius Erichson (Col. Palp.). Bulletin et Annales de la Société Entomologique de Belgique 76: 425-438.

ORCHYMONT A. D’ 1940: Les Palpicornia des Îles Atlantiques. Mémoires du Musée Royale d'Histoire Naturelle de Belgique, 2. série 20: 1-87.

PALLARÉS S., ARRIBAS P., BILTON D. T., MILLÁN A., VELASCO J. \& RIBERA I. 2017: The chicken or the egg? Adaptation to desiccation and salinity tolerance in a lineage of water beetles. Molecular Ecology 26: 5614-5628.

PEDERZANI F. 2003: Hydaticus satoi dhofarensis n. ssp. from Oman (Insecta Coleoptera Dytiscidae). Quaderno di Studi e Notizie di Storia Naturale della Romagna 17: 17-24.

RÉGIMBART M. 1897: Dytiscides recueillis à Mascate par M. Maurice Maindron. Bulletin de la Société Entomologique de France 1897 206-208.

RIBERA I. \& AGUILERA P. 1996: Els Estanys de Capmany: the missing Spanish pingo (or palsa) fens? Latissimus 7: 2-6.

RIBERA I., VOGLER A. P. \& BALKE M. 2008: Phylogeny and diversification of diving beetles (Coleoptera, Dytiscidae). Cladistics 24: 563-590.

ROCCHI S. 1984: Insects of the Yemen Arab Republic. Coleoptera: Fam. Haliplidae, Dytiscidae, Gyrinidae. Fauna of Saudi Arabia 6: 444-450.

RUDOY A., BEUTEL R. G. \& RIBERA I. 2016: Evolution of the male genitalia in the genus Limnebius (Coleoptera, Hydraenidae). Zoological Journal of the Linnean Society 178: 97-127.

SCHÖDL S. 1998: Taxonomic revision of Enochrus (Coleoptera: Hydrophilidae). 1. The E. bicolor species complex. Entomological
Problems 29: 111-127.

SHAVERDO H., MONAGHAN M. T., LEES D., RANAIVOSOLO R. \& BALKE M. 2008: A new genus of Malagasy endemic diving beetles and description of a highly unusual species based on morphology and DNA sequence data (Dytiscidae: Copelatinae). Systematics and Biodiversity 6: 43-51.

SHORT A. E. Z. \& FIKÁC̆EK M. 2013: Molecular phylogeny, evolution and classification of the Hydrophilidae (Coleoptera). Systematic Entomology 38: 723-752.

SKALE A. \& JÄCH M. A. 2011: Updating the Hydraena fauna of Iran, with descriptions of eight new species (Insecta: Coleoptera: Hydraenidae). Vernate 30: 185-216.

SKALICKÝ S. 2004: Revision of Asian Heteroceridae described by Mamitza (1933), with descriptions of four new species from Laos and Myanmar (Coleoptera: Heteroceridae). Koleopterologische Rundschau 74: 399-412.

SKALICKÝ S. 2014: New species and new records of Heteroceridae from the Arabian Peninsula and neighbouring areas (Coleoptera: Heteroceridae). Koleopterologische Rundschau 84: 305-312.

TRIZZINO M., JÄCH M. A., AUDISIO P., ALONSO R. \& RIBERA I. 2013: A molecular phylogeny of the cosmopolitan hiperdiverse genus Hydraena Kugelann (Coleoptera, Hydraenidae). Systematic Entomology 38: 192-208.

VILLASTRIGO A., FERY H., MANUEL M., MILLÁN A. \& RIBERA I. 2018: Evolution of salinity tolerance in the diving beetle tribe Hygrotini (Coleoptera, Dytiscidae). Zoologica Scripta 47: 63-71.

VILLASTRIGO A., JÄCH M. A., CARDOSO A., VALLADARES L. F. \& RIBERA I. 2019: A molecular phylogeny of the tribe Ochthebiini (Coleoptera, Hydraenidae, Ochthebiinae). Systematic Entomology 44: 273-288.

WEWALKA G. 1992: Revisional notes on Palearctic species of the Hydroporus planus group (Coleoptera: Dytiscidae). Koleopterologische Rundschau 62: 47-60.

WEWALKA G. \& BISTRÖM O. 1998: Glareadessus gen.n. with description of two new species from the Persian Gulf region (Coleoptera: Dytiscidae). Koleopterologische Rundschau 68: 59-63.

WEWALKA G. \& JÄCH M. A. 2017: Description of Copelatus djiboutensis sp.n., and notes on C. gestroi (Sharp, 1882) (Coleoptera: Dytiscidae). Koleopterologische Rundschau 87: 15-26.

WOLLASTON T. V. 1864: Catalogue of the coleopterous insects of the Canaries in the collection of the British Museum. London, British Museum, xiii +648 pp.

WOLLASTON T. V. 1867: Coleoptera Hesperidum, being an enumeration of the coleopterous insects of the Cape Verde archipelago. London, J. van Voorst, xxxix +285 pp. 